\title{
DUSZPASTERSTWO EMIGRACJI POLSKIEJ W RZYMIE I INNYCH KRAJACH WLOSKICH W LATACH 1795-1863: OKOLICZNOŚCI POWSTANIA, POSTULATY I KIERUNKI BADAWCZE
}

W XVIII wieku poza wyjazdami o charakterze podróżniczym i edukacyjnym Italia stała się przystanią dla emigrantów politycznych. Przegrana wojna polsko-rosyjska 1792 roku i objęcie władzy przez targowiczan spowodowały emigrację twórców i zwolenników Konstytucji 3 maja, którzy udali się do Saksonii, Austrii, Włoch i Francji. Po klęsce powstania kościuszkowskiego i III rozbiorze Polski wyemigrowało z kraju około 4 tys. osób ${ }^{1}$. Znaczna grupa wychodźców politycznych skupiła się wówczas w Wenecji. Pod koniec 1794 roku przebywało tutaj około 50 Polaków, w tym 1 senator, 7 posłów i 7 członków rządu insurekcyjnego, 3 dyplomatów, 6 generałów, 8 oficerów wyższych i niższych, 2 duchownych. Ogółem w latach 1795-1796 przewinęło się przez Wenecję blisko 130 polskich tułaczy. Poza emigrantami politycznymi w Wenecji pojawiły się grupy Polaków spod zaborów, tzw. paszportowi, którzy z różnych przyczyn udawali się z paszportem państw zaborczych za granicę. Do osiedlania się w tym właśnie mieście skłaniało jego centralne położenie i neutralność Republiki Weneckiej. Majątkami dysponowali wówczas na Półwyspie Apenińskim Stanisław Potocki, bratanek ostatniego króla Polski, podskarbi wielki koronny (pałac w Rzymie, majątek pod Florencją), oraz pisarz polny Franciszek Michał Rzewuski (pałace we Florencji

Dr hab. Jerzy Kuzicki, prof. UR - Instytut Historii Uniwersytetu Rzeszowskiego; e-mail: jkuzicki@wp.pl

${ }^{1}$ W. ŚLAdKowsKi, Wychodźstwa polskiego zarys dziejowy, Lublin 1994, s. 13; S. KaLemBKA, Polskie wychodźstwa popowstaniowe i inne emigracje polityczne w Europie w XIX wieku, w: Polska XIX wieku. Państwo, społeczeństwo, kultura, red. S. Kieniewicz, Warszawa 1977, s. 194. 
i Pizie) $)^{2}$. W stolicy Toskanii wychowywało się pięcioro dzieci księcia Stanisława ze związku z Cassandrą Luci Benloch, które w XIX wieku odegrały znaczną rolę w dziejach Florencji. Pałac Piccolellis, znajdujący się niedaleko kościoła San Michelino, znany był z wystawnych przyjęć, uważano go również za salon literacki ${ }^{3}$. Przez Legiony Polskie, które utworzył gen. Jan Henryk Dąbrowski u boku Napoleona Bonaparte, przewinęło się prawie 30 tys. Polaków, głównie z zaboru austriackiego, którzy przebywali w obozach jenieckich we Włoszech i Francji. W połowie 1797 roku w formacjach legionowych we Włoszech znajdowało się ponad 5500 ludzi. Po kongresie wiedeńskim uczestnicy Legionów Polskich oraz oficerowie i żołnierze armii Księstwa Warszawskiego w większości zaciągnęli się do wojsk Królestwa Polskiego. Nieliczni zdecydowali się pozostać na emigracji, wśród nich był gen. Józef Grabiński, który już w 1808 lub 1809 roku pozostał na stałe w zakupionej posiadłości ziemskiej pod Bolonią, a w 1831 roku stanął na czele lokalnego powstania ${ }^{4}$.

W ciągu kilku stuleci - od schyłku XVI do XIX wieku - w Rzymie zmarło wielu Polaków w bardzo młodym wieku, wkrótce po przybyciu do miasta. Prawdopodobnie ci ludzie i ich rodziny, przesiąknięci głęboką wiarą, poszukiwali w Wiecznym Mieście ratunku dla ciężko chorych, cudownego uzdrowienia. Oczywiście na tego rodzaju pielgrzymki mogły sobie pozwolić zamożne rodziny. Świadczą o tym polskie nazwiska utrwalone na cmentarnych inskrypcjach: Narbutt, Tyszkiewicz, Łubieńska, Plater, Jazłowiecki, Rzewuska itd. ${ }^{5}$ Zdaniem ks. Ireneusza Korzeniowskiego, który przytacza dane opracowane przez o. J. Sulżyckiego TChr, Włochy przyjęły w okresie lat 1831-1864 ponad 300 emigrantów polskich, wśród nich około 70 emigrantów - powstańców z 1831, 1848 i 1864 roku. W grupie tej byli m.in. płk Jarosław Dąbrowski, gen. Maurycy Hauke-Bosak, Walery Wróblewski ${ }^{6}$. Jak ocenił

2 J. Pachoński, Legiony Polskie. Prawda i legenda 1794-1807, t. I: Działalność niepodległościowa i zaczątki Legionów 1794-1797, Warszawa 1976, s. 66-67.

${ }^{3}$ H. Lorenc-Antonangeli, Potomkowie księcia Stanistawa Poniatowskiego, w: Polonia wtoska. Wybór artykułów z Biuletynu Informacyjnego „Polonia Wloska” z lat 1995-2009, wybór i opracowanie tekstów E. Prządka, A. Kwiatkowska, Rzym 2010, s. 258-262.

${ }^{4}$ E.M. ZıóŁeK, Duszpasterstwo w wojsku Księstwa Warszawskiego, Królestwa Polskiego i w powstaniu listopadowym, w: Historia duszpasterstwa wojskowego na ziemiach polskich, red. J. Ziółek, A. Barańska, W. Matwiejczyk, D. Nawrot, E.M. Ziółek, Lublin 2004, s. 173-179; J. Kozıowski, Emigracja okresu schytkowego Rzeczypospolitej szlacheckiej i porozbiorowa, w: Emigracja z ziem polskich w czasach nowożytnych i najnowszych (XVIII-XX w.), red. A. Pilch, Warszawa 1984, s. 49. Więcej zob. J. PAChoŃski, Legiony Polskie 1794-1807. Prawda i legenda, t. I-IV, Warszawa 19691979, passim.

5 M. Borucki, Polacy w Rzymie. Od czasów Mieszka I do Jana Pawła II, Warszawa 1995, s. 100. Zob. więcej: M.I. KwiatKowska, Groby polskie na cmentarzach Rzymu, Warszawa 1999, passim.

${ }^{6}$ I. Korzeniowski, Polacy we Włoszech. Zarys historii, duszpasterstwa, organizacji i prasy, „Studia Polonijne” 21(2000), s. 122-123. 
Jerzy Borejsza, po upadku powstania styczniowego do krajów włoskich przybyło około 300 emigrantów polskich ${ }^{7}$. W XIX wieku w Rzymie gościło wielu polskich romantyków literatów i artystów, m.in.: Adam Mickiewicz, Antoni Edward Odyniec, Zygmunt Krasiński, Delfina Potocka, Juliusz Słowacki, Cyprian Kamil Norwid, Stefan Witwicki, Teofil Lenartowicz, Józef Bohdan Zaleski. Malarstwo i rzeźbę studiowali w Akademii św. Łukasza m.in.: Tomasz Oskar Sosnowski, Wojciech Korneli Stattler, January Suchodolski, Jan Nepomucen Głowacki. W drugiej połowie XIX i w pierwszej połowie XX wieku podróże do Włoch i pobyty w Rzymie stają się inspiracją m.in. dla Henryka Sienkiewicza, Józefa Ignacego Kraszewskiego czy Stefana Żeromskiego ${ }^{8}$.

Polacy przebywający w pierwszej połowie XIX wieku na Półwyspie Apenińskim, podobnie jak i w innych częściach ówczesnej Europy i świata, wymagali opieki duchowej ze strony rodowitych księży. Jak słusznie zauważył ks. prof. Bernard Kołodziej, dla zachowania polskiej tożsamości na emigracji wielkie znaczenie miały specyficzne formy duszpasterstwa. Oprócz ustalonych w całym Kościele katolickim form sakramentów, liturgii i innych przepisów, Kościół na ziemiach polskich wypracował przez wieki odrębne nabożeństwa. Należały do nich m.in.: Wigilia Bożego Narodzenia, nabożeństwo Gorzkich Żali, przeżywanie Wielkiego Tygodnia, prywatne nabożeństwa majowe i różańcowe ${ }^{9}$. Duszpasterstwo polonijne byłoby niepotrzebne, gdyby nie różniło się od duszpasterstwa miejscowego. Funkcjonowanie placówek duszpasterstwa polonijnego oznaczało uwzględnienie odmiennego stylu duszpasterzowania poprzez dopuszczenie różnych elementów, właściwych rodzimej kulturze i religijności, przede wszystkim mentalności polskiej grupy etnicznej ${ }^{10}$. Dzieje duszpasterstwa polskiego w Państwie Kościelnym i innych częściach Włoch były już przedmiotem opracowań opublikowanych w „Studiach Polonijnych""1 , jak również prac zbiorowych i wydawnictw pokonferencyjnych, jednakże koncentrowały się one na XX i XXI wieku ${ }^{12}$. W zbiorowym opracowaniu pt. Duchowieństwo polskie w świecie. Materiały VII Międzynarodowego

7 J. BoressZA, Emigracja polska po powstaniu styczniowym, Warszawa 1966, s. 19-41.

${ }^{8}$ H. BARYCZ, Spojrzenia w przeszłość polsko-włoska, Wrocław-Warszawa-Kraków 1965, s. 333349; M. Borucki, Polacy, s. 100-120; A. Kwiatkowska, „Pod urokiem Italii” - Podróże polskich pisarzy do Włoch, w: Polonia włoska, s. 305-307.

9 B. KoŁodzieJ, Opieka duszpasterska nad wychodźcami polskimi do roku 1939, Poznań 2003, s. $17-18$.

10 J. SZYMański, Duszpasterstwo polonijne - skala oddziaływania, „Studia Polonijne” 28(2007), s. 13.

${ }^{11}$ H. MiszTal, Duszpasterstwo Polonii wtoskiej, „Studia Polonijne” 1(1976), s. 183-197; I. KoRZENIOWski, Polacy we Włoszech, s. 121-130.

12 Zob. np. Wkład Polaków do kultury świata, red. M. Krąpiec [i in.], Lublin 1976; Działalność męskich zgromadzeń zakonnych wśród Polonii, red. J. Bakalarz [i in.], Lublin 1982. 
Sympozjum Biografistyki Polonijnej. Papieski Uniwersytet Urbaniański, Rzym, 17-18 października 2002 (red. A. i Z. Judyccy, Toruń 2002) znalazło się miejsce dla kilku sylwetek duchownych pracujących wśród Polonii włoskiej ${ }^{13}$. Polska historiografia może pochwalić się szeregiem biografii, encyklopedii i słowników, w których można znaleźć dane biograficzne księży i zakonników pracujących wśród emigrantów w krajach włoskich ${ }^{14}$. Pomimo tego tematyka duszpasterstwa polskiego w pierwszej połowie XIX wieku w Państwie Kościelnym i Włoszech wymaga szczegółowych badań.

Niniejszy artykuł nie jest próbą monograficznego opracowania dziejów duszpasterstwa polskiego w krajach włoskich w XIX wieku. Przybliżenie tej tematyki musi poprzedzać wieloletnia kwerenda źródłowa w polskich i zagranicznych archiwach i bibliotekach. Autor tego opracowania, prowadząc badania nad duchowieństwem i duszpasterstwem emigracji polistopadowej we Francji i na Wyspach Brytyjskich ${ }^{15}$, wielokrotnie zetknął się z tematyką określoną w tytule artykułu. To zainspirowało go do ukazania opieki duszpasterskiej w Rzymie i w krajach włoskich. Poza tym zamiarem autora było przybliżenie nowych źródeł dotyczących tej problematyki. W artykule pominięto wątki polityczne działań zmartwychwstańców, Hotelu Lambert i polskich ośrodków w Wiecznym Mieście.

${ }^{13}$ Zob. W. CABAN, P. BIENIEK, Kardynat Włodzimierz Czacki (1835-1888) - wspótpracownik Piusa IX i Leona XIII, w: Duchowieństwo polskie w świecie, s. 38-42; Z. GrocholewsKI, Reprezentant polski w Kurii Rzymskiej. Kardynat Bolesław Jan Filipiak (1901-1978), w: tamże, s. 105-113; M. InGLOT, Włodzimierz Ledóchowski SJ (1866-1842). Generat Towarzystwa Jezusowego, w: tamże, s. 130-135; J. KopIEC, Ks. Walerian Meysztowicz (1893-1982). Dyplomata, prawnik i historyk w stużbie swojego kraju, w: tamże, s. 143-149; W. ZARĘBCZAN, Polscy pracownicy naukowi na papieskich uczelniach w Rzymie, w: tamże, s. 383-396.

${ }^{14}$ Polski stownik biograficzny, t. I-LII, Kraków 1935-2018; Encyklopedia katolicka, t. I-XVIII, Lublin 1973-2013; Encyklopedia polskiej emigracji i Polonii, red. K. Dopierała, t. I-V, Torun 20032005; Encyklopedia wiedzy o jezuitach na ziemiach Polski i Litwy 1564-1995, opracował L. Grzebień, Kraków 1996; J. KACHEL, Bernardyni 1453-2003. Kapłani i bracia zakonni prowincji polskich oraz kustodii św. Michała na Ukrainie, cz. V, R-T, Warta 2004; Misjonarze św. Wincentego à Paulo w Polsce (1651-2001), t. II-1: Biografie, red. J. Dukała, Kraków 2001; Z. JudYCKI, Polscy duchowni w świecie. Stownik biograficzny, t. I, Kielce 2008; A. i Z. Judyccy, Polonia. Stownik biograficzny, Warszawa 2000; A. i Z. JudyCCY, W stużbie Bogu i światu. Stownik biograficzny. Polscy i polskiego pochodzenia kapłani, zakonnicy $i$ siostry zakonne petniąy postugę $w$ różnych krajach świata, Toruń 2002; W. ZarębCZan, Polacy w Watykanie, Pelplin 2004; Polonia włoska, passim.

15 J. KuZIcki, Nieść wiarę i nadzieję na obcej ziemi. Polskie duchowieństwo katolickie $w$ życiu religijnym i polityczno-społecznym Wielkiej Emigracji we Francji (1831-1863), Rzeszów 2014; TENŻE, Duchowieństwo Wielkiej Emigracji na Wyspach Brytyjskich (1831-1863), „Studia Polonijne” 32(2011), s. 6-33. 
Dla wyjeżdżających z kraju pielgrzymów Rzym był często miejscem docelowym. Dla nich też w Wiecznym Mieście powstał pierwszy polski ośrodek duszpasterski. W 1578 roku kardynał Stanisław Hozjusz objął w posiadanie kościół pod wezwaniem św. Stanisława, biskupa. Przy tym rzymskim kościele dobudowano potem hospicjum polskie, przeznaczone dla pielgrzymów. Kościół ten aż do czasów rozbiorów Polski pełnił rolę rodzimego ośrodka duszpasterskiego w stolicy chrześcijaństwa ${ }^{16}$. W XVIII wieku środowisko polskie w Wiecznym Mieście miało już pewne tradycje. Tworzyli je nie tylko duchowni, ale także pielgrzymi i podróżni. Polska kolonia w Rzymie w początkach XVIII wieku była dobrze widoczna na tle dziejów miasta. Trzeba pamiętać, że w Rzymie przebywała królowa Maria Kazimiera Sobieska wraz z licznym dworem, skupiającym nie tylko Polaków. Środowisko Polonii rzymskiej stanowiło wielu młodych duchownych, pogłębiających swą wiedzę, m.in. Józef Andrzej Załuski, Kajetan Sołtyk, Franciszek i Gabriel Podoscy, Ignacy Massalski, Wacław Sierakowski, Ignacy Krasicki, Michał Jerzy Poniatowski, Hugo Kołłątaj. Obok studentów i pielgrzymów nad Tybrem pojawiają się podróżnicy, przeważnie arystokraci, jak Michał Jerzy Mniszech, August Moszyński, bracia Stanisław Kostka i Ignacy Potoccy ${ }^{17}$. Jak pisał ks. bp Jan Kopiec, ważnym źródłem do poznania m.in. duszpasterstwa Polaków w XVIII wieku w Wiecznym Mieście jest archiwum Hospicjum św. Stanisława przy via delle Botteghe Oscure 15. Znajduje się tam 7 ksiąg protokołów zebrań i uchwał zarządu Hospicjum. Można w nich znaleźć informacje o składzie osobowym tej instytucji, tzw. rewizorach, o stanie kasy, wydatkach i podejmowanej działalności. Na podstawie tych archiwaliów można się zorientować co do składu kolonii polskiej, jej problemów, ważnych dla duszpasterstwa spotkań i uroczystości religijnych ${ }^{18}$.

Legiony Polskie powołano w styczniu 1797 roku na terenie młodej Republiki Lombardzkiej, którą utworzono po zwycięstwie Francji nad Austrią i wyzwoleniu spod jej władzy północnych Włoch. Część wyższych oficerów z dowództwa Legionów Polskich była obojętna religijnie, a niektórzy odnosili się z niechęcią do papieża Piusa VI. Niemniej ogromna większość oficerów i żołnierzy była głęboko religijna. Legioniści tłumnie uczęszczali do włoskich kościołów, gorszyli się zajmowaniem przez Francuzów świątyni i klasztorów na koszary, sprzedawaniem sprzętów kościelnych Żydom. Nieraz ścierali się z Francuzami manifestującymi

${ }^{16}$ B. KolodzieJ, Opieka duszpasterska, s. 35-36; A.M. LePacka, Poczatki Kolegium Polskiego w Rzymie, „Studia Warmińskie” 50(2013), s. 263-269.

17 M.I. Kwiatkowska, Polacy $w$ Rzymie $w$ wiekach XIX-XX, Warszawa 2007, s. 12.

18 J. KopIEC, Echa polskich wydarzeń z lat 1704-1709 w środowisku Hospicjum św. Stanisława w Rzymie, „Nasza Przeszłość” 1994, t. 82, s. 373-380. 
swą bezbożność. W kwietniu 1798 roku do Rzymu skierowano I legię polską. Pierwszy wjechał do Rzymu gen. Jan Henryk Dąbrowski, który zatrzymał się po drodze wraz z wojskiem w Loreto - w sanktuarium Matki Boskiej. Polscy żołnierze spowiadali się wówczas u polskiego franciszkanina Piotra Falęckiego. W Rzymie zaś legioniści korzystali z posługi franciszkanina o. Franciszka Laudańskiego, penitencjariusza w Bazylice św. Piotra. W chwili, gdy Polacy wkroczyli do Rzymu, kościół św. Stanisława był opieczętowany i znajdował się w dyspozycji administratora republikańskiego Gamliniego. W 1796 roku ówczesny rektor kościoła, ks. Józef Puszet, oraz prowizorzy musieli oddać świątynię rządowi rosyjskiemu. Trzeba dodać, że w okresie napoleońskim kościół św. Stanisława został ogołocony z kosztowności ${ }^{19}$. Twórca Legionów Polskich, gen. J.H. Dąbrowski wkrótce po wkroczeniu I legii do Rzymu w maju 1798 roku rozkazał otwarcie polskiego kościoła, którego prefektem został bernardyn Gabriel Sokołowski, przebywający nad Tybrem od 30 lat, nieoficjalny kapelan Legionów Polskich. Swoją pomoc duszpasterską zadeklarowali też inni księża polscy: Ignacy Zdzieborski, Kamiński i unita o. Jordan Mickiewicz. Powierzono im nie tylko pracę duszpasterską, ale także oświatową i wychowawczą wśród żołnierzy. Inny duchowny, ks. Stanisław Staniszewski zrzucił nawet sutannę, podejmując rolę emisariusza. Niektórzy klerycy rzymscy - Dembiński, Milewski, Skwarski wstąpili w szeregi Legionów Polskich, wkrótce zresztą polegli. W tym czasie podjęto wysiłek dla odzyskania dawnych fundacji w Rzymie i Loreto. Polacy mogli wówczas zgłaszać pretensje do innego rzymskiego kościoła - św. Piotra w Okowach, zakupionego przy pomocy króla Stanisława Augusta Poniatowskiego od cystersów dla polskich księży marianów ${ }^{20}$.

W czasie wojny neapolitańskiej gen. J.H. Dąbrowski, mając pod swymi rozkazami dywizję nadgarigliańską, zjednał sobie zarówno biskupa Gaety - Riccarda Minutolo, jak i biskupa Traetty - Vincenza Stazio. W okresie funkcjonowania Legii Naddunajskiej można było odnotować uczestnictwo żołnierzy polskich w uroczystościach religijnych w Toskanii i Florencji. Po podpisaniu konkordatu wprowadzono do wojsk francuskich, włoskich i polskich kapelanów. Kapelanem 1 regimentu polskiej piechoty Legii Nadwiślańskiej został ks. Francesco Comandelli, a jazdy ks. Giovanni Maria Gritti. W końcowym okresie legionowym Polakom z Korpusu Inwalidów i Weteranów przydzielono jako kapelana ks. Giovanniego Francesco Castillona. W szpitalach Mediolanu i Modeny, gdzie przebywali ranni

19 J. PACHOŃSKI, Legiony Polskie. Prawda i legenda 1794-1807, t. II: Zwycięstwa i klęski 17971799, Warszawa 1976, s. 115-116; M. MaCHeJEK, 400 lat Kościoła i Hospicjum św. Stanisława $w$ Rzymie, Rzym 1978, s. 38-40; L. Henczel-WróBlewsKa, Polacy $w$ kulturze Piemontu $w$ XIX wieku i w pierwszych dekadach XX wieku, Poznań 2014, s. 48-49.

20 J. PACHOŃsKi, Korpus oficerski Legionów Polskich 1796-1807, Kraków 1999, s. 64, 115-118; E.M. ZıóŁeK, Duszpasterstwo, s. 173-179. 
żołnierze polscy, kapelanami byli włoscy księża - Gaetano Pergamo i Giovanni Battista Colla ${ }^{21}$. Wymienieni księża to tylko niektórzy duchowni prowadzący duszpasterstwo wśród żołnierzy polskich we Włoszech. Było ich więcej, jednakże ustalenie ich nazwisk wymaga dalszych badań źródłowych. Pomocne tutaj mogą być archiwa włoskie i francuskie. Z badań autora wynika, że zbiory Archiwum Ministerstwa Wojny w Vincennes zawierają interesujące nas materiały ${ }^{22}$.

Wydarzenia lat 1830-1831 nad Wisłą dodawały nadziei Włochom, walczącym w powstaniu w środkowej Italii. Po upadku polskiego powstania doszło do ożywionych kontaktów polskich emigrantów z włoskimi karbonariuszami i Giuseppe Mazzinim. Rządy państw włoskich, będące w przymierzu z Austrią, nieufnie patrzyły na tułaczy znad Wisły, o ich przyjęciu nie mogło być mowy ${ }^{23}$. Jak wiadomo, pobyt emigrantów polistopadowych w Państwie Kościelnym był również formalnie zabroniony. Polityka państw zaborczych doprowadziła do poważnego ograniczenia kontaktów polskiego duchowieństwa ze Stolicą Apostolską. Biskupi nie odbywali pielgrzymek ad limina Apostolorum, a zgodę na podróż do Rzymu udawało im się uzyskać tylko wyjątkowo. Łatwiej niż księża i zakonnicy docierali do Rzymu katolicy świeccy. Do 1830 roku polscy arystokraci odwiedzając Stolicę Apostolską ograniczali się na ogół do zwyczajnych audiencji u papieża za rekomendacją właściwego ambasadora. Nieprzemyślane konstytucje Sejmu Rzeczypospolitej z 1764 i 1768 roku oraz dekret króla Stanisława Augusta Poniatowskiego z 1789 roku pozwoliły Rosji przywłaszczyć sobie Kościół i Hospicjum św. Stanisława. Od 1814 roku polskim Hospicjum przy kościele św. Stanisława zarządzał kanonik Giovanni Battista Piva, życzliwy Polakom, który starał się wykupić kościół. Nie mógł jednak urządzać tam polskich nabożeństw. Z lat 30. XIX wieku pochodzą polskie pomniki w kościele: ks. Stanisława Parczewskiego i Doroty Lubomirskiej. Już od czasu powstania listopadowego dyplomaci carscy dążyli do rusyfikacji hospicjum przy kościele św. Stanisława. Instytucja wiodła mizerny żywot, w latach 1857-1874 zanotowano tylko 114 pielgrzymów, w tym 19 Rosjan. Jeszcze mniej pątników znalazło się tam w późniejszym okresie ${ }^{24}$.

${ }^{21}$ J. PACHOŃSKI, Korpus oficerski, s. 120-121.

${ }^{22}$ Archiwum Ministerstwa Obrony Francji (Service Historique de l'Armée de Terre - SHAT), $\mathrm{XL}-9^{\mathrm{a}-\mathrm{f}}$ lère Légion de la Vistule: dossiers des 4 régiments. Réfugiés polonais sous le $1^{\text {er }}$ Empire : pièces individuelles $\mathrm{A}$ à $\mathrm{Z}$.

${ }^{23}$ K. Morawski, Polacy i sprawa polska $w$ dziejach Italii $w$ latach 1830-1866, Warszawa 1930, s. $31-40,55$.

${ }^{24}$ M. MachejeK, 400 lat Kościoła i Hospicjum, s. 37, 41, 90-91; A. BARAŃSKA, Kościót i przemiany religijności $w$ historii Polski XIX wieku, w: Historie Polski w XIX wieku, red. A. Nowak, t. IV, Warszawa 2015, s. 52-53. 
Pomijając aspekt polityczny działań polskich środowisk w Wiecznym Mieście należy zauważyć, że nowy rozdział duszpasterstwa polskiego w Rzymie wiązał się z przybyciem późniejszych zmartwychwstańców, którzy od 1837 roku przygotowywali się nad Tybrem do kapłaństwa. Przez pierwszy rok akademicki klerycy Piotr Semenenko i Hieronim Kajsiewicz mieszkali u ojców somasków przy Piazza Capranica. Ale już pod koniec 1838 roku powstał osobny dom rzymski, przy Piazza Morgana 24. Od początku były plany utworzenia ośrodka duszpasterskiego, który miał się zajmować pielgrzymującymi rodakami. W 1840 roku do Rzymu z Paryża przeniosło się centrum tworzącego się zgromadzenia. W pierwszej fazie działalności zmartwychwstańców wśród Polonii włoskiej stosowano metody apostolatu świeckich Bogdana Jańskiego, wypracowane we Francji. Odbywały się prywatne rozmowy na tematy związane z katolicyzmem, zachęcano do lektury książek religijnych oraz organizowano cotygodniowe konferencje na Piazza Morgana. Później, gdy pierwsi uczniowie Jańskiego otrzymali święcenia i założyli zgromadzenie, doszły do tego metody kapłańsko-duszpasterskie. 1 września 1842 roku rząd francuski powierzył zmartwychwstańcom w zarząd jeden z francuskich kościołów, św. Klaudiusza, przy placu św. Sylwestra. Odtąd aż do 1886 roku kościół ten stał się centrum polskiego duszpasterstwa. O. Józef Hube został mianowany rektorem kościoła, otrzymał uposażenie i mieszkanie na parterze. Pomagali mu ks. Piotr Semenenko oraz klerycy: Hipolit Terlecki, Karol Kaczanowski i Władysław Godlewski, od 1843 roku ks. Aleksander Jełowicki. Skład misji rzymskiej ulegał częstym zmianom, od 1845 roku na jej czele stał ks. H. Kajsiewicz, który został przełożonym zmartwychwstańców. W latach 1847-1855 rządził zgromadzeniem oraz misją rzymską ponownie ks. J. Hube, któremu pomagał ks. Alfred Bentkowski, a po jego przedwczesnej śmierci księża Kajsiewicz i Semenenko. Od 1855 roku zgromadzeniem i duszpasterstwem w Rzymie z powrotem kierował ks. Kajsiewic ${ }^{25}$. Początkowo dochód rektora wynosił jedynie 3 skudy. W celu pomieszczenia całej wspólnoty mieszkającej przy Piazza Morgana, wynajęto dodatkowe pokoje na Viccolo Mortaro 58, za które płacono 13 skudów ${ }^{26}$. Dzięki pozyskanym ofiarom udało się przeprowadzić w kościele św. Klaudiusza remont zakrystii, ołtarzy bocznych oraz zakupić nowe sprzęty liturgiczne ${ }^{27}$.

Od początku pobytu w Wiecznym Mieście zmartwychwstańcy utrzymywali kontakt z polską kolonią. W kościele św. Klaudiusza kardynał Giacomo Filippo Franzoni w marcu 1845 roku udzielał Polakom sakramentu bierzmowania, mówiąc

25 B. Micewski, Polonijna działalność zmartwychwstańców, w: Działalność męskich zgromadzeń zakonnych wśród Polonii, red. J. Bakalarz [i in.], Lublin 1982, s. 411-412.

26 ACRR, sygn. 17201, A. Jełowicki do H. Kajsiewicza, Rzym, 17 III 1844; tamże, sygn. 17207, A. Jełowicki do H. Kajsiewicza, Rzym, 18 I 1845.

27 ACRR, sygn. 17210, A. Jełowicki do H. Kajsiewicza, Rzym, 8 III 1845. 
przy tym Io sono vescovo dei Polacchi. Daj nam Boże takich! Wśród tułaczy przyjmujących ten sakrament znalazł się Cyprian Norwid, który wówczas przybrał drugie imię Kamil ${ }^{28}$. Z Polaków przebywających w Rzymie w zimie 1846 roku ks. Kajsiewicz wymienił, oprócz stale mieszkających księżnej Zofii z Potockich Odescalchi i Anny Branickiej z niezamężną córką, następujące osoby: żonę Andrzeja Zamoyskiego z córkami, Ryszczewską z córką i synem Aleksandrem, Tadeusza Walewskiego z żoną, Karola i Aleksandra Przeździeckich z rodzinami, Tyzenhauza, Aleksandra Branickiego, Grocholskich z córkami, księżnę Czetwertyńską, Bielińskich, Rembielińskich, Niedziałkowskich z Sandomierskiego, Wisłockiego i Sieckiego z Litwy, Prozorów, Mirskich, Ciechanowickich z Białorusi, Sobańską, Giżycką, Łubieńskich, Celińskiego, Jankowskiego, Rohozińskiego, Podhorskiego. Do tych należało dodać ,z 10 artystów z kraju i emigrantów i ze 40 służących” ${ }^{29}$. Poza duszpasterstwem zmartwychwstańcy w Rzymie przyjmowali stałe kapelanie w domach zamożnych Polaków, np. Łubieńskich, Poniatowskich. Łubieńscy posiadali prywatną kaplicę, gdzie odprawiano msze i spowiadano Polaków ${ }^{30}$. Zmartwychwstańcy wspomagali też polskich misjonarzy. Ks. Kajsiewicz wspominał: „W Rzymie też spotkać można misjonarzy rozjeżdżających się w różne strony świata. A że wszędzie są Polacy zaopatrywaliśmy ich w duchowne książki polskie, które tak dostawały się nie tylko na Kaukaz i nad Wołgę, ale na wyspy Sandwich"31. Praca apostolska dotyczyła również Włochów, prowadził ją m.in. ks. Luigi Marchetti, później Antonini - Włosi, którzy mieszkali we wspólnocie jako kapłani współpracownicy. Ks. Karol Kaczanowski przygotowywał uroczystości okresowe i nabożeństwa majowe, które cieszyły się takim powodzeniem, że niepokoił się, czy nie zdominują życia religijnego sąsiednich parafii i nie odciągną wiernych. Kościół św. Klaudiusza był własnością rządu francuskiego, a rektor

28 P. Sмoliкowski, Historia Zgromadzenia Zmartwychwstania Pańskiego. Podtug źródet rękopiśmiennych napisat [...], t. IV, Kraków 1896, s. 293. W humorystyczny sposób opisywał tę uroczystość ks. Jełowicki: „W Bazylice naszej mieliśmy uroczystość nie do opisania bierzmowanie publiczne 14 Polaków pod wąsem i 4 Polek wobec całej obecnej tu Polski, kardynał Franzoni był pośrednikiem. (...) Trzeba by wybierzmować tym sposobem wasze tysiąc Polaków paryskich” (zob. ACRR, sygn. 17212, A. Jełowicki do H. Kajsiewicza, Rzym, 3 IV 1845; M.I. Kwiatkowska, Polacy, s. 37).

${ }^{29}$ H. Kajsiewicz do J. Koźmiana, Rzym, 20 V 1846, w: H. KaJsiewicz, Listy 1845-1847, t. III, red. T. Kaszuba, Rzym 2005, s. 110-111.

30 „Bylebyśmy nie zmarnowali kościoła, możemy teraz zająć trzy kapelanie stałe w nim, a czwartą u Łubieńskich tj. 300 skudów na rok" (zob. H. Kajsiewicz do Ojców i Braci CR w Paryżu, Rzym, 21 VIII, 6 XII 1855, w: H. KAJSIEWICZ, Listy, t. VI, s. 71, 133).

${ }^{31}$ Cyt. za: http: //www.biz.xcr.pl/files/KAJSIEWICZ-Pamietnik-o-Poczatkach-CR.pdf [dostęp: 09.07.2018]. Tekst oryginalny za: Pisma X. Hieronima Kajsiewicza ze Zgromadzenia Zmartwychwstania Pańskiego, t. III, Rozprawy, Listy z podróży, Pamiętnik o Zgromadzeniu, Berlin [w Księgarni B. Behra (E. Bock)] - Kraków [w Księgarni D.E. Friedleina], 1872, s. 402-527. Komputerowe opracowanie tekstu: Michał Szlachciak CR, s. 32. 
pozostawał całkowicie od niego zależny. To stawało się nieprzyjemne, ponieważ zmartwychwstańcy byli traktowani przez dyplomatów znad Sekwany jak żebracy. Sytuację tę opisuje w jednym z listów ks. Aleksander Jełowicki: „Wiesz zapewne, że Francja ma tu kościołów pięć, każdy z tych kościołów ma osobne uposażenie. Tymczasem wbrew sprawiedliwości zbito wszystkie te fundusze $\mathrm{w}$ jedną masę i zamurowano w kościół św. Ludwika, który ubogacają, a resztę zjadają (...). Zaś św. Klaudiusz, który przed przejściem do nas był otwierany na pół godziny tylko dziennie, to jest na dwie msze kwadransowe, i był nędzny, brudny, opuszczony itd, teraz jest czysty i ludny. Otwarty przez cały dzień, jak wielkie kościoły w Rzymie. Są w nim kazania i wszelkie nabożeństwa najwykwintniejsze, tak dalece, iż przez duszyczki pobożne nazywany jest Petit Jesus"32.

Opieką duszpasterską zostali objęci Polacy na stale mieszkający w Wiecznym Mieście, jak i wojażujący po Włoszech. Ks. A. Jełowicki pisał: „Zapewne będziesz się tam widział z księżną Zinaidą [Wołkońską - przyp. J.K.], która w sobotę wieczór pojechała do Neapolu z całym domem. U księżny Borghese byłem w niedzielę, bardzo dobrze przyjęła [...] powiedziała jakiś ks. Hube wziął 80 skudów [...] Obiecała ks. Borghese być u nas w piątek na mojej mszy, przyniosła to nad odprawianą u niej, aby odwiedzić kościół św. Klaudiusza"33. Zmartwychwstańcy od 1844 roku chcieli nabyć w Rzymie klasztor wraz z kościołem. Mający wpływy wśród Polonii ks. Jełowicki pozyskał pewne fundusze na ten cel u Seweryny z Potockich Sobańskiej i Zofii z Giżyckich Łubieńskiej. Planowano zakup budynku pod jednym z kilku adresów w Rzymie: przy via Frattina, via Monte Cavallo, klasztor trynitarzy przy via Condotti lub wynajęcie kościoła Matki Bożej wystawionego jako wotum zwycięstwa pod Wiedniem. Z powodów finansowych nie zrealizowano tych zamierzen ${ }^{34}$. Ks. Kajsiewicz marzył, aby „dom rzymski był katolicki i przestał być li [tylko] polsko-emigracyjnym ${ }^{35}$. Zimą 1856 roku w domu zmartwychwstańców było „4 lub 5 braciszków, 10 lub 11 studentów i nowicjuszów, i 6 albo 7 księży w Rzymie"36. Zmartwychwstańcy podejmowali w latach 40. i 50. XIX wieku ćwiczenia duchowe dla Polek przy via Paulina, prowadzili też dla pielgrzymów i podróżnych z kraju rekolekcje adwentowe i wielkopostne oraz indywidualne rozmowy duchowe ${ }^{37}$. Jak pisał ks. Kajsiewicz: „,...] kościół

${ }^{32}$ A. Jełowicki do H. Kajsiewicza, Rzym, 17 III 1844, w: P. SmoLıкowski, Historia Zgromadzenia Zmartwychwstania Pańskiego. Podtug źródet rękopiśmiennych napisał, t. III, Kraków 1893, s. 131-132.

33 ACRR, sygn. 17189, A. Jełowicki do J. Hubego, Rzym, 20 X 1843.

34 ACRR, sygn. 17206, A. Jełowicki do H. Kajsiewicza, Rzym, 28 XI 1844.

${ }^{35}$ H. Kajsiewicz do Braci w Paryżu, Livarno, 6 XI 1846, w: H. KaJsiewicz, Listy, t. III, s. 184.

${ }^{36}$ H. Kajsiewicz do A. Jełowickiego, Rzym, 6 IX 1856, w: H. KaJsiewicz, Listy 1855-1858, t. VI, red. T. Kaszuba, Rzym 2007, s. 233.

37 B. Micewski, Polonijna działalność, s. 411-414. 
św. Klaudiusza to narzędzie naszej misji dla Polaków, to pozycja nasza względem Włochów i Francuzów, to nareszcie 500 sk.[udów] dochodu"38.

W latach 1847-1848 księża polscy zarządzali w Rzymie Towarzystwem Historycznym, które było placówką naukową zajmującą się badaniami archiwalnymi. Instytucja ta powstała z inspiracji Stanisława Egberta Koźmiana i gen. Józefa Szymanowskiego. Kwerendę archiwalną prowadził głównie Ludwik Jastrzębski, a finansował ją Adam Potocki. Poza tym zmartwychwstańcy założyli w Wiecznym Mieście Towarzystwo Wsparcia dla biednych emigrantów i artystów, którego pierwotny fundusz wyniósł 3000 franków ${ }^{39}$. W 1847 roku jak pisał ks. Kajsiewicz: „W czasie Wielkiego Tygodnia mieliśmy 6 nauk. Komunię [świętą] Generalną, Bierzmowanie i wszystkie funkcje, które się tu pobożnie odbyły, że rozgłos poszedł po całym Rzymie" ${ }^{40}$. Rekolekcje wielkopostne przeprowadzano regularnie, corocznie, czasem towarzyszyły temu inne formy duszpasterskiego oddziaływania, jak w 1851 roku zainicjowano dziewięciodniowe nabożeństwa wielkopostne z kazaniami oraz uroczyste triduum do Matki Boskiej ${ }^{41}$. W okresie po Bożym Narodzeniu 1852 roku kazania głosili księża Kajsiewicz i Semenenko, „Słuchaczów było ze 40 ”42. Ks. Karol Kaczanowski, który po wojnie krymskiej przebywał w Rzymie, pisał: „Ja biegam z roznoszeniem opłatków. Podług tedy statystyki opłatkowej dotąd odkryłem 18 familii polskich, może biegając znajdę więcej”. Do przyjaciół zgromadzenia należał gen. Józef Szymanowski, który po upadku powstania listopadowego mieszkał w Rzymie ${ }^{43}$. W 1856 roku, jak wynika z korespondencji zmartwychwstańców: „Teraz mamy msze [święte] śpiewane, co niedzielę i święto i śpiew idzie coraz lepiej. Kazania bywają polskie, włoskie i angielskie" 44 .

W kościele odbywały się msze pogrzebowe za zmarłych w Wiecznym Mieście rodaków, np. w styczniu 1846 roku za Jerzego Sobolewskiego, w kwietniu 1847 roku za poetę Stefana Witwickiego i gen. Stanisława Klickiego ${ }^{45}$. Rezultaty pracy duchowej opisywał ks. Kajsiewicz: „Mieliśmy tu dość i ciężkiej pracy przez post,

${ }^{38}$ H. Kajsiewicz do A. Jełowickiego, Rzym, 29 IX 1855, w: H. Kajsiewicz, Listy, t. VI, s. 92.

39 H. Kajsiewicz do P. Semenenki, Rzym, 7 II 1847, w: H. Kajsiewicz, Listy, t. III, s. 204; J. KuZICKI, Nieść wiarę, s. 635-636.

${ }^{40}$ H. Kajsiewicz do P. Semenenki, Rzym, 8 IV 1847, w: H. Kajsiewicz, Listy, t. III, s. 211.

${ }^{41}$ H. Kajsiewicz do A. Jełowickiego, Rzym, 24 IV [18] 51, w: H. KaJsiewicz, Listy 1848-1851, t. IV, red. T. Kaszuba, Rzym 2006, s. 211.

${ }^{42}$ H. Kajsiewicz do J. Hubego, Rzym, 30 XII 1852, w: H. KaJSIEwICZ, Listy 1852-1854, t. V, red. T. Kaszuba, s. 100.

${ }^{43}$ ACRR, sygn. 20645, K. Kaczanowski do A. Jełowickiego, Rzym, 18 XII 1857.

${ }^{44}$ H. Kajsiewicz do K. Kaczanowskiego, Rzym, 9 XII 1856, w: H. KaJsIEwICz, Listy, t. VI, s. 266.

45 H. Kajsiewicz do K. Królikowskiego, Braci CR w Paryżu, Rzym, 28 IV 1847, w: H. KaJsIEwICZ, Listy, t. III, s. 212-213, 215. 
ale też i wielkie pociechy, bo wielką widzieliśmy korzyść w duszach. Wszyscy prawie odbywali spowiedź powszechną, a do Stołu Pańskiego z wielkim szli płaczem, aż Włosi patrząc płakali z rozczulenia"46. Uroczysta msza pogrzebowa odbyła się w czerwcu 1846 roku po śmierci papieża Grzegorza XVI ${ }^{47}$. W kościele św. Klaudiusza odbyły się uroczyste egzekwie za ofiary rzezi galicyjskiej odprawione 22 lutego 1848 roku $^{48}$. W 1848 roku odprawiono mszę pogrzebową za zmarłą Joannę Tyszkiewiczową, w czasie której mowę pogrzebową wygłosił ks. Aleksander Jełowicki ${ }^{49}$. W 1855 roku uroczyście odbywano tutaj trzydniowe nabożeństwo z okazji ogłoszenia dogmatu o Niepokalanym Poczęciu Najświętszej Marii Panny ${ }^{50}$. Na początku 1858 roku misja rzymska uczciła nabożeństwem żałobnym śmierć kardynała Michała Lewickiego, metropolity lwowskiego obrządku greckokatolickiego ${ }^{51}$. Ks. Jełowicki głosił wiosną tego roku w kościele kazania poświęcone św. Wojciechowi, jednemu z patronów polskich ${ }^{52}$. Po wydarzeniach w Warszawie w 1861 roku rzymscy zmartwychwstańcy odprawili mszę św. za poległych. Miała ona, jak pisał ks. Semenenko, uroczysty charakter: „Obecni byli w żałobie, milczenie uroczyste. Wielkie wrażenie zostawiła prosta ta ceremonia

${ }^{46}$ H. Kajsiewicz do K. Łubieńskiego, Rzym, 4 V 1846, w: tamże, s. 96.

${ }^{47}$ H. Kajsiewicz do Braci CR w Paryżu, Rzym, 27 I, 8 VI 1846, w: tamże, s. 73, 117.

48 M.I. Kwiatkowska, Polacy, s. 37-38.

49 A. JeŁowicki, Mowa pogrzebowa na cześć Joanny z Tyszkiewiczów Tyszkiewiczowej miana czasu jej pogrzebu w Rzymie, w kościele św. Klaudiusza dnia 19 marca 1848, w: A. JeŁowicki, Kazania o świętych polskich i o Królowej Korony Polskiej tudzież nauki przedślubne, mowy pogrzebowe i kazania przygodne przez księdza... poprzedzone listami Ojca Świętego Piusa IX a zakończone dokumentami odnoszacymi się do założenia Seminarium Polskiego w Rzymie i nauka o roztropności chrześcijańskiej św. Wincentego à Paulo, Berlin 1872, s. 365-371.

50 „Ponieważ tej zimy (z roku 1854 na 1855) odbywały się kolejno po rozmaitych kościołach rzymskich nabożeństwa trzydniowe, na podziękowanie Panu Bogu za nowe uwielbienie Najświętszej Maryi Panny: na żądanie pobożnych rodaków, i z ich pomocą, i myśmy takowe Triduum odbyli na zakończenie tegorocznego zimowego nabożeństwa dla Polaków w dniach 13, 14, i 15 Kwietnia. Kościółek św. Klaudiusza był pięknie przybrany, rzęsiście oświecony, a bogactwem kwiatów i pięknem ich ułożeniem wszystkie kościoły przesadził, (jak to się też dzieje przy corocznem ubieraniu grobu Pańskiego). Pisał o tem triduum dziennik urzędowy rzymski, i po dwakroć Univers paryski. Ponieważ dnia 12go Kwietnia zdarzył się ów tragiczny wypadek zawalenia się Ojca św. wraz z całym dworem u św. Agnieszki: myśmy pierwsi nazajutrz odśpiewali Te Deum, dziękując za uratowanie" (cyt. za: http: //www.biz.xcr.pl/files/KAJSIEWICZ-Pamietnik-o-Poczatkach-CR.pdf [dostęp: 09.07. 2018], s. 25-27).

${ }^{51}$ B. Micewski, Polonijna działalnośćc, s. 413.

52 A. JeŁowicki, Kazanie o świętym Wojciechu męczenniku, Arcybiskupie Gnieźnieńskim, Patronie Królestwa Polskiego miane $w$ Rzymie $w$ kościele św. Klaudiusza, w pierwsza niedziele po Święcie Zmartwychwstania Pańskiego, $r$. 1858, w: A. JeŁOWICKI, Kazania na święta patronów polskich i na rocznice narodowe, Lwów 1912, s. 16-31. 
samym milczeniem wymowną i uroczystą żałobą poważna"53. Kapłani w misji rzymskiej po wybuchu powstania styczniowego zorganizowali stałe modły za Ojczyznę. A w sierpniu 1863 roku udało się zmartwychwstańcom wyjednać u papieża Piusa IX publiczne modlitwy za Polaków ${ }^{54}$.

W 1854 roku rzymska misja zmartwychwstańców uzyskała pierwszą własność pod Rzymem w postaci letniej rezydencji i małej winnicy „La Camillucia”, z fundacji Zofii z Giżyckich Łubieńskiej, na utrzymanie kilku księży w Rzymie do obsługi Polaków. Z czasem kościół św. Klaudiusza stał się ciasny i niewygodny, szczególnie w miesiącach letnich. Ciasnota zmusiła o. Kajsiewicza do rozpoczęcia poszukiwań bardziej odpowiedniego domu. Mieszkańcy winnicy w Camillucia byli trapieni wówczas przez malarię, a wynajdowanie mieszkań w Tivoli lub Albano zbyt dużo kosztowało. Te poszukiwania zakończyły się nieoczekiwanie, gdy Pius IX powierzył zmartwychwstańcom w 1857 roku klasztor Matki Boskiej Łaskawej z Mentorelli. Ta zabytkowa świątynia okazała się zrujnowana i położona z dala od Rzymu, z bardzo ograniczonymi możliwościami prowadzenia pracy duszpasterskiej. Mimo to stała się symbolem działań pierwszych zmartwychwstańców. Tutaj odbywały się rekolekcje dla członków zgromadzenia i rzymskich pielgrzymów ${ }^{55}$. Jeśli chodzi o aktywność duszpasterską zmartwychwstańców w stolicy chrześcijaństwa, ciekawe materiały znajdują się w archiwum zgromadzenia w Rzymie przy San Sebiastanello. W zbiorach tego archiwum przechowywane są tysiące listów, dokumentów osobistych, rękopisów oraz różnorodnych prac pierwszych zmartwychwstańców. W korespondencji przewijają się nazwiska wielu osób, świeckich i duchownych, które znajdowały się w państwach włoskich. Przykładowo - już 19 lutego 1838 roku przyszli zmartwychwstańcy nawiązali kontakt z polskim jezuitą z Modeny o. Franciszkiem Obręmpalskim, który jako profesor teologii promował thumaczenie książek religijnych na język polski. Był on przyjacielem mającej duży wpływ wśród rzymskiej Polonii hrabiny Wandy z Potockich Caboga. Później zmartwychwstańcy współpracowali z innymi polskimi jezuitami: Rajmundem Brzozowskim, Józefem Alojzym Dmowskim, Romualdem Suszyńskim, Maksymilianem Ryłło ${ }^{56}$. Poza tym należy pamiętać, że została opublikowana drukiem korespondencja pierwszych zmartwychwstańców - o. Hieronima Kajsiewicza i Piotra Semenenki, gdzie w niektórych fragmentach przewijają się wątki rzymskiego duszpasterstwa.

53 Cyt. za: P. Smolikowski, Historia Kolegium Polskiego w Rzymie. Podług źródeł rękopiśmiennych napisat [...], Kraków 1896, s. 37.

${ }^{54}$ B. Micewski, Polonijna działalność, s. 415.

55 J. IwICKI, Charyzmat Zmartwychwstańców. Historia Zgromadzenia Zmartwychwstania Pańskiego, t. I (1836-1886), Katowice 1990, s. 166-169.

56 Więcej o tych zakonnikach zob. Encyklopedia wiedzy o jezuitach, s. 73, 125, 469, 589. 
Z działaniami duszpasterskimi zmartwychwstańców wiąże się powstanie Kolegium Polskiego w Rzymie. Już w XVI wieku św. Filip Neri przygotowywał się do założenia takiej instytucji, zachęcony przez kardynała Savellego, protektora spraw polskich. Oratorianie wynajęli pomieszczenia dla Kolegium Polskiego i 1 września 1582 roku otworzyli go za aprobatą papieża Grzegorza XIII. Kolegium przetrwało wówczas tylko cztery lata, głównie z powodu śmierci króla Stefana Batorego, braku zainteresowania ze strony Episkopatu Polskiego oraz ze względu na niedostatek funduszy na jego funkcjonowanie. W tym okresie w instytucji kształciło się pięciu polskich alumnów. Król polski Jan Kazimierz był zainteresowany powstaniem kolegium polsko-szwedzkiego w kościele św. Brygidy, pod kierunkiem jezuitów. Król pisał dwukrotnie w kwietniu 1653 roku w tej sprawie do papieża Innocentego X. Kolegium polsko-szwedzkie funkcjonowało już latem 1653 roku, a jego administratorem został kardynał Virginio Orsini. Na listach studentów z tego okresu jest wiele polskich nazwisk. Po śmierci Jana Kazimierza w 1672 roku patronat nad kolegium objęła królowa szwedzka Krystyna, która zezwoliła na zamieszkanie i studiowanie tam wyłącznie szwedzkim studentom, co położyło kres istnienia kolegium polsko-szwedzkiego. Pomysł zorganizowania kolegium wrócił w czasach porozbiorowych, gdy w 1836 roku, cztery lata przed śmiercią, Bogdan Jański, współzałożyciel zmartwychwstańców, wrócił do tej idei. Uczniowie Jańskiego, P. Semenenko i H. Kajsiewicz, podjęli wysiłek na rzecz jego reaktywacji. Dyskutowano o tym m.in. z jezuitą o. Suszyńskim. Zabiegi te doprowadziły do założenia Kolegium Greckiego, przy poparciu nuncjusza wiedeńskiego ks. Altieriego i hojności Wandy z Potockich Caboga. Otwarcie nastąpiło 21 listopada 1845 roku, którego dokonał ks. Jełowicki, a o jego utrzymanie dbał ks. H. Kajsiewicz. Rektorem tego instytutu został sekretarz nuncjatury wiedeńskiej $^{57}$. Początkowo przebywało tam siedmiu kleryków z unickich diecezji lwowskiej i przemyskiej. Ks. Jełowicki pełnił obowiązki spowiednika oraz nauczyciela katechizmu, ks. Kraiński prowadził dla kleryków lekcje języka włoskiego ${ }^{58}$. Na początku lat 50. XIX wieku ks. Semenenko zredagował notę do papieża, w której podkreślał potrzebę utworzenia w Wiecznym Mieście instytucji dla polskich kapłanów i przypomniał o istnieniu Kolegium Greckiego, które borykało się z licznymi trudnościami. $Z$ ewentualnego utworzenia kolegium polsko-greckiego płynęłyby liczne korzyści, gdyż nie byłoby potrzeby szukania dla niego pomieszczeń i można by oszczędzić na kosztach funkcjonowania. Ks. Jełowicki przekazał

57 M. StęPIEŃ, Początki Kolegium Polskiego w Rzymie w XVI i XVII w. oraz działania zmierzajace do jego utworzenia w XIX w., „Prawo Kanoniczne” 53 (2010), nr 1-2, s. 299-314; J. IwICKI, Charyzmat, t. I, s. 261-262.

58 ACRR, sygn. 20645, A. Jełowicki do H. Kajsiewicza, Rzym, 28 XI 1845. 
notę hrabiemu Montalembertowi, który przekazał ją nuncjuszowi we Francji, kardynałowi Fornariemu, a ten duchowny z kolei Piusowi IX, który obawiał się nazwy kolegium polskie. Niestety zmartwychwstańcy stracili opiekę nad Kolegium Greckim, ponieważ przyłączono go do Kolegium Rozkrzewiania Wiary. Dopiero za pontyfikatu papieża Leona XIII Kolegium Greckie znów wróciło pod zarząd zmartwychwstańców, a jego rektorami byli ks. Antoni Lechert, ks. Walenty Lanciotti i ks. Augustyn Mosser ${ }^{59}$.

W 1850 roku w Rzymie przebywał francuski parlamentarzysta Charles Montalembert, który w czasie spotkania z Piusem IX podał propozycję zorganizowania w Wiecznym Mieście seminarium polskiego pod kierownictwem zmartwychwstańców dla kleryków z Galicji i Poznańskiego. Książę Adam Jerzy Czartoryski gotów był wesprzeć tę instytucję finansowo, przeznaczając rocznie na ten cel 5000 franków $^{60}$. W drugiej połowie lat 50 . XIX wieku nadarzyła się sposobność nabycia klasztoru Umiltà po siostrach wizytkach: ,[...] rodzina zamożna z Litwy, która szczerze myśli, aby część dać, część ukwestować nam na kupienie klasztoru", chciała przeznaczyć 3000 rubli. Zakup zamierzali współfinansować także inni rodacy: Łubieńscy, Orłowska, Gruszecki, Dariusz Poniatowski. Zmartwychwstańcy wychodzili z założenia, że kościół św. Klaudiusza był jedynie dzierżawiony, a kościół św. Stanisława, choćby udało się odzyskać, to „zawsze nie będzie dom nasz" ${ }^{\prime}$. Jednakże wówczas dyplomaci rosyjscy, austriaccy i pruscy zgłosili protest, co pogrzebało projekt. W 1857 roku zmartwychwstańcy próbowali wykorzystać okoliczność, że wielu Polaków zgromadziło się w Ostendzie w Belgii, aby zdobyć wśród nich fundusze na rzecz bursy dla księży w Rzymie. Poza tym księża Semenenko i Kajsiewicz w czasie podróży do zaboru pruskiego i austriackiego zabiegali u tamtejszych biskupów o pomoc dla seminarium polskiego. Powstanie styczniowe przyspieszyło założenie Kolegium Polskiego. Stolica Apostolska przekonała się, że wpływ zaborców na duchowieństwo polskie jest szkodliwy i potrzeba jej księży i zakonników całkowicie oddanych Kościołowi, wychowanych w Wiecznym Mieście. Dodatkowo pomogła okoliczność, że ks. Aleksander Jełowicki zebrał od 1850 roku ponad 100 tys. franków na budowę kościoła polskiego w Paryżu.

59 M. StęPIEŃ, Początki Kolegium Polskiego, s. 306; J. IwICKI, Charyzmat, t. I, s. 261-278; B. Micewski, Polonijna działalność, s. 412.

${ }^{60}$ M. StęPIEŃ, Początki Kolegium Polskiego, s. 305; ACRR, sygn. 17761, A. Jełowicki do H. Kajsiewicza, 20 XII 1856. Kilka miesięcy później ks. Jełowicki pisał: „W rzeczy składki na kupno klasztoru w Rzymie książę bardzo ostygł. Mówił mi wczoraj, że pieniędzy nie ma, że książę Władysław mu mówił, że jeszcze nic oznaczonego, a tym samym starania godnego" (tamże, sygn. 17767, A. Jełowicki do H. Kajsiewicza, 28 II 1857).

${ }^{61}$ H. Kajsiewicz do K. Królikowskiego, Rzym, 27 VIII 1856; H. Kajsiewicz do J. Hubego, Rzym, 28 VIII 1856, w: H. KaJsiewicz, Listy, t. VI, s. 226, 228. 
Po zasięgnięciu opinii ofiarodawców i uzyskaniu przychylnej decyzji władz zgromadzenia, pieniądze te zostały wykorzystane na założenie w 1866 roku Kolegium Polskiego w Rzymie przy via Salaria Vecchia (później, od 1878 roku, przy via Maroniti 22). Dodatkowe fundusze pozyskano wśród Polaków w kraju i na emigracji. Poza zmartwychwstańcami, wielką rolę w powstaniu kolegium odegrali księżna Odescalchi i jej siostrzeniec, prałat, późniejszy kardynał Włodzimierz Czacki $^{62}$. W drugiej połowie XIX wieku i na początku XX wieku misją rzymską kierowali kolejno następujący zmartwychwstańcy: ks. H. Kajsiewicz (1855/18571873), ks. P. Semenenko (1873-1886), ks. Walerian Przewłocki (1887-1895), ks. Paweł Smolikowski (1895-1905), ks. Jan Kasprzycki (1905-1920) i ks. Władysław Zapała (1920-1926) ${ }^{63}$.

Od 1833 roku przebywał nad Tybrem agent dyplomatyczny emigracyjnego obozu księcia Adama Jerzego Czartoryskiego. Rzymska agencja Hotelu Lambert obok celów politycznych i religijnych dążyła również do wyjednania pewnych ustępstw na rzecz polskiego duchowieństwa i pielgrzymów. Proponowano m.in. powołanie w Rzymie bursy dla polskich księży oraz powołanie Towarzystwa Naukowej Pomocy. Jednakże kolejni agenci księcia Czartoryskiego, jak: Adam Sołtan (1834-1837), Władysław Zamoyski (1837 i 1842), Cezary Plater (1838-1839), Michał Czajkowski (1840-1841) i Ludwik Orpiszewski (1844-1848), nie zdołali zdobyć większych wpływów wśród rzymskiej Polonii. Tutaj zmartwychwstańcy mieli lepsze kontakty z polskimi rodzinami Szymanowskich, Rzewuskich, Zinaidą Wołkońską, Dorotą Czartoryską, księżną Borghese, Zofią z Branickich Odescalchi, Zofią z Giżyckich Łubieńską. W salonach arystokracji polscy księża spotykali rodaków z kraju i mogli duchowo na nich oddziaływać ${ }^{64}$. W sprawozdaniach agentów dyplomatycznych Hotelu Lambert, które znajdują się w Bibliotece Czartoryskich w Krakowie, można znaleźć informacje o Polakach w Wiecznym Mieście oraz o działaniach duszpasterskich zmartwychwstańców ${ }^{65}$. Przykładowo można w tym kontekście

${ }^{62}$ J. Iwicki, Charyzmat, t. I, s. 270-278; M. STęPIeń, Początki Kolegium Polskiego, s. 306-313.

63 B. Micewski, Polonijna działalność, s. 417-418.

${ }^{64}$ Więcej zob. S. KalemBKa, Polskie zabiegi dyplomatyczne między powstaniem listopadowym a styczniowym (koniec 1831-1860 r.), w: Historia dyplomacji polskiej, t. III: 1795-1918, red. L. Bazylow, Warszawa 1982, s. 280-290; J. WszoŁeK, Działalność polityczna obozu Czartoryskiego wśród Polaków w Rzymie w latach 1832-1843, „Przegląd Historyczny” 1967, t. 58, z. 4, s. 625-643.

65 Biblioteka Czartoryskich w Krakowie, rkps 5374 IV - „X[iążę] A[dam] C[zartoryski]. Rome. Correspondances avec le Pape 1840 à [18]41. Tome II”; tamże, rkps 5375 IV - „X[iążę] A[dam] C[zartoryski]. Rome. Correspondances avec le Pape 1842 à [18]43. Tome III"; tamże, rkps 5376 IV - „X[iążę] A[dam] C[zartoryski]. Rome. Correspondances avec le Pape 1844 à [18]46. Tome IV”; tamże, rkps $5378 \mathrm{IV}$ - „X[iążę] A[dam] C[zartoryski]. Rome. Correspondances avec le Pape 1848 à [18]60. Tome VI”; tamże, rkps 5379 IV - „X[iążę] A[dam] C[zartoryski]. Rome. Correspondance de Czaykowski 1840 à [18]42. Tome VII”; tamże, rkps 5380 IV - „X[iążę] A[dam] C[zartoryski]. Rome. 
przytoczyć fragment listu Michała Czajkowskiego do księcia Czartoryskiego: „Rzym jest bardzo ważnym punktem ze wszech miar. Książę Pan winien mieć tu dwóch nie jednego wysłannika tj. jednego poddanego władzy drugiego [...]. Jest to ważne stanowisko, najważniejsze, jakie dziś w emigracji można powierzyć”66. W 1837 roku Adam Sołtan, jako przedstawiciel Czartoryskiego, zwrócił uwage hierarchów papieskich na konieczność przekazania oo. bazylianom rzymskiego kościoła Madonna del Pascolo (obecnie unicki kościół śś. Sergiusza i Bakchusa). Kościół ten z obrazem Matki Boskiej Żyrowickiej był restaurowany w XVII wieku przez litewskiego szlachcica Sołtana. Został on nadany bazylianom w 1639 roku przez papieża Urbana VIII, za wstawiennictwem kardynała Barberiniego. Znaleziony około 1719 roku w zakrystii kościoła malowany na murze wizerunek Matki Boskiej, zupełnie był podobny do tego, który znajdował się w Żyrowicach. W okresie sprawowania rządów w zakonie bazylianów w Rzymie przez o. Ignacego Kulczyckiego, w 1729 roku został postawiony marmurowy ołtarz, na który przy nabożeństwie odprawionym przez połockiego arcybiskupa unickiego, Floriana Hrebnickiego, przeniesiono obraz w uroczystej procesji przy udziale licznych mieszkańców Rzymu. Odtąd kościół ten lud zaczął nazywać Najświętszej Panny Marii Żyrowickiej lub La Madonna del Pascolo (Madonna na Pastwisku). W 1794 roku rektorem tego kościoła, a zarazem prokuratorem bazylianów był o. Jordan Mickiewicz, który pomimo trudności powiększył fundusz świątyni ${ }^{67}$. W okresie zaborów kościół ten był, podobnie jak polski, św. Stanisława, pod kontrolą rosyjskiego przedstawicielstwa dyplomatycznego. Świątynia wówczas opustoszała, następnie przyjęta została w zarząd papieski przez duchowieństwo francuskie. Zdaniem przedstawicieli Hotelu Lambert, kościołem Madonna del Pascolo powinni zarządzać sprowadzeni z Galicji bazylianie, którzy mieli zająć się duszpasterstwem grekokatolickich pielgrzymów z ziem polskich. Wobec trudności związanych ze sprowadzeniem zakonników nad Tybr, planów tych nie zrealizowano ${ }^{68}$. Istotna w tym kontekście jest zgromadzona w Bibliotece Czartoryskich korespondencja wieloletniego agenta księcia Czartoryskiego w Rzymie, Ludwika Orpiszewskiego. Poza listami zmartwychwstańców można tam trafić na pisma od mieszkających we Włoszech Polaków: Teofila Lenartowicza, gen. Józefa Szymanowskiego, Zofii

Correspondances de L. Orpiszewski 1844 à [18]49. Tome VIII”; tamże, rkps 5381 IV - „X[iążę] A[dam] C[zartoryski]. Rome. Diverses correspondances. Tome IX”; tamże, rkps 5382 IV - „Rzym 1848”.

${ }^{66} \mathrm{BCz}$, rkps 5374 IV, k. 303-313, M. Czajkowski do A. J. Czartoryskiego, 1840 z Rzymu.

${ }^{67}$ M. BALIŃski, T. LiPIŃski, Starożytna Polska pod względem historycznym, jeograficznym i statystycznym opisana przez [...], t. III, Warszawa 1846, s. 689-690.

68 J. KuzICKI, Stronnictwo konserwatywno-liberalne Wielkiej Emigracji wobec grekokatolików w Galicji, w: Cirkvi a národy strednej Európy (1800-1950), zestavili P. Švorc, L. Harbul'ová, K. Schwarz, Prešov-Wien 2008, s. 181-192. 
z Branickich Odescalchi, księżnej Borghese. Ze swej strony książę Adam Jerzy Czartoryski prowadził korespondencję z Sekretariatem Stanu, zwracając uwagę na potrzeby duszpasterskie emigrantów ${ }^{69}$. Podobne, jak wyżej wskazane listy, znaczenie dla odtworzenia działań religijnych może mieć korespondencja siostrzeńca księcia, Władysława Zamoyskiego ${ }^{70}$. Ważnym źródłem do poznania działań Polonii w Piemoncie i innych państwach włoskich jest korespondencja Hotelu Lambert z przywódcami tych państw oraz działaczami włoskimi i polskimi. W Bibliotece Czartoryskich zdeponowano m.in. pisma Polaków i ich rejestry imienne ${ }^{71}$.

Wspomniano tutaj o ośrodku rzymskim skupionym wokół Zofii z Branickich Odescalchi, córki Władysława Branickiego i Róży Potockiej, żony od 1841 roku Liwiusza III Odescalchi, potomka znanej, choć zubożonej rodziny lombardzkiej. Małżeństwo Odescalchich zdobyło z czasem wielkie wpływy wśród rzymskich hierarchów, a ich pałac przy Piazza Sancti Apostoli i dobra w Bracciano były od lat 40. aż po lata 80. XIX wieku zapleczem dla emigrantów i działań polskich. W okresie pontyfikatów Grzegorza XVI i Piusa IX księżna Zofia zaangażowała się, wspólnie ze zmartwychwstańcami, w sprawę Makryny Mieczysławskiej, rzekomej przełożonej bazylianek w Mińsku, a w rzeczywistości mistyfikatorki. Wraz z ks. A. Jełowickim zorganizowała zbiórkę pieniędzy i współfinansowała własną ofiarą zakup w Rzymie opuszczonego klasztoru z niewielkim kościołem. Kościół ten księżna Zofia podarowała Mieczysławskiej, aby mogła założyć tam nowe zgromadzenie (na terenie dzisiejszego Piazza Vittorio Emanuele) ${ }^{72}$. Wcześniej matka Makryna mieszkała w klasztorze Trinità dei Monti zgromadzenia Sacré Coeur. „Męczennica za wiarę” cieszyła się początkowo wielką sławą i wywarła ogromny wpływ na polskich poetów, pielgrzymów i emigrantów. Należy przy tym dodać, że polska kolonia w Wiecznym Mieście otaczała czcią fresk Mater Admirabilis

${ }^{69} \mathrm{BCz}$, rkps 6747 IV, Archiwum Hotelu Lambert. „Rzym. Stolica Apostolska”. Korespondencja Adama Jerzego Czartoryskiego z papieżem Piusem IX, 1848-1860.

70 Tamże, rkps 6967 IV, Archiwum Hotelu Lambert. Władysław Zamoyski. Korespondencja. Pewne informacje zawiera wydana drukiem korespondencja, zob. Jenerat Zamoyski 1803-1868, t. III, 1832-1837, Poznań 1914; t. IV, 1837-1847, Poznań 1918; t. V: 1847-1852, Poznań 1922; t. VI, 1853-1868, Poznań 1930.

${ }^{71}$ BCz, rkps 5622 IV, „Correspondances, 1855. Tome I”; tamże, rkps 5681 IV, „Lista imienna, 1853-1854-1855”. Wykazy emigrantów polskich przebywających we Francji, Anglii, Włoszech i Afryce; tamże, rkps 5699 III, „Agence romaine. Mai 1861 - septembre 1863”; tamże, rkps 5745 IV, „Agence romaine. /Paris 1. 1863-1865”; tamże, rkps 5746 IV, „Agence romaine. /Paris 1. 1863-1864”. Archiwum agencyjne „Memoranda i noty do Rządu Jego Świątobliwości”; tamże, rkps 6743, Archiwum Hotelu Lambert. Materiały dotyczące stosunków polsko-włoskich w latach 1848-1849 oraz 1860-1863.

72 A. BARAŃsKA, ,Polska ambasador” przy Watykanie - Zofia z Branickich Odescalchi (18211886), w: Od Paryża do Irkucka ... i dalej. Niecodzienne przypadki Polaków okresu niewoli narodowej, red. A. Barańska, E. Niebelski, Lublin 2017, s. 77-98; J. Urban, Makryna Mieczysławska w świetle prawdy, Kraków 1923, passim. 
w klasztorze Trinità dei Monti. Przy ścianie korytarza klasztoru urządzono małą kaplicę. Pieniądze na ten cel w dużej mierze wyłożył Edward Jełowicki - brat ks. Aleksandra. Pierwsze msze św. odprawili w niej zmartwychwstańcy: Kajsiewicz i Semenenko. Fresk utrwalił się w kulturze polskiej dzięki Cyprianowi Kamilowi Norwidowi, który w sumie spędził w Rzymie około dwóch i pół roku, mieszkał przy Piazza Barberini, via Sistina i Piazza di Spagna ${ }^{73}$.

W pałacu przy Piazza Sancti Apostoli przebywali polscy arystokraci, działacze polityczni, literaci, artyści i duchowni. Obok dwóch szwagrów Zofii Odescalchi, Zygmunta Krasińskiego i Adama Potockiego, bywali tam m.in.: generał Władysław Zamoyski, Stanisław Małachowski, August Cieszkowski, Jerzy Lubomirski, Leon Rzewuski, Maurycy Mann. Zbierało się tu grono młodych, uzdolnionych prałatów, którzy z czasem zajęli ważne stanowiska w hierarchii kościelnej. Aby zapewnić zamieszkanie i środki do życia emigrantom, księżna Odescalchi założyła na przedmieściach Rzymu rodzaj gospodarstwa rolnego, ale przedsięwzięcie to zakończyło się niepowodzeniem. Zarządzała ona również stypendiami dla artystów i księży polskich. Ufundowała i wyposażyła rzymskie klasztory i zakłady dobroczynne, np. szpital dla chorych księży pod wezwaniem Niepokalanej Dziewicy Bogarodzicy i św. Józefa, klasztory sióstr św. Anny i sióstr Bożej Miłości. Z czasem księżna Zofia zdobyła stopniowo na dworze papieskim pozycję doradcy i „szarej eminencji” w zakresie polskich spraw kościelnych. Dom Odescalchich, jako centralna instytucja polonijna w Rzymie zachował polski charakter, księżna we współpracy ze zmartwychwstańcami urządzała u siebie „polskie święta”, np. na Wielkanoc odbywało się tradycyjne święcone ${ }^{74}$.

W innych krajach włoskich w pierwszej połowie XIX wieku raczej nie było możliwości do zorganizowania duszpasterstwa dla Polaków, ponieważ nie mieszkały tam zbyt liczne grupy tułaczy. Według dokumentów policyjnych z Turynu z lat 1821-1848, przez terytorium Piemontu przewinęło się około 90 Polaków. Uczestnicy Wielkiej Emigracji zostali stamtąd wydaleni w 1832 roku z powodu podejrzeń o działalność rewolucyjną. W okresie Wiosny Ludów wielu emigrantów polskich przebywało w Piemoncie, byli to zarówno członkowie Legionu Adama Mickiewicza, jak również działacze z Hotelu Lambert. W świetle dokumentów z turyńskich archiwów można potwierdzić obecność około 800 Polaków, którzy od lat 40. do 80. XIX wieku przebywali na ziemi piemonckiej dłuższy lub krótszy czas. Przed wybuchem powstania styczniowego w Genui i Cuneo funkcjonowały szkoły wojskowe, które przygotowywały kadry powstańcze. Ochotników polskich

73 E. PrząDKA, Matka Boska Przedziwna - Mater Admirabilis w klasztorze Trinità dei Monti w Rzymie, w: Polonia wloska, s. 263-267.

74 A. BARAŃSKA, „Polska ambasador” przy Watykanie, s. 99-132. 
można było spotykać w szeregach garibaldczyków i innych oddziałów walczących o zjednoczenie Włoch ${ }^{75}$. Sfery rządowe w Neapolu śledziły ruchy poszczególnych rewolucjonistów polskich i trzeba przyznać, że były dobrze o nich poinformowane. Konsul Generalny Królestwa Obojga Sycylii w Państwie Kościelnym miał szczegółowe instrukcje, aby emigrantom polskim nie udzielać wiz wjazdowych ${ }^{76}$. Z przekazów źródłowych pochodzą nieliczne informacje, że księża polscy nie ograniczali swej posługi duchowej do granic Państwa Kościelnego. W czasie podróży po krajach włoskich zmartwychwstańcy spotykali podróżujących rodaków i prowadzili z nimi rozmowy religijne. W 1846 roku ks. H. Kajsiewicz kontaktował się w Genui z Dernałowiczem i jego drugą żoną Kuplową, która „także do Włoch przyjechała umierać z suchot”. Ponadto spotkał tam Świejkową i Grabowską $\mathrm{z}$ dziećmi ${ }^{77}$. Z rodziną Poniatowskich przez dłuższy czas ks. Semenenko podróżował po krajach włoskich ${ }^{78}$. W 1856 roku ks. Kajsiewicz przebywał m.in. w Aquili w państwie neapolitańskim, gdzie jeździł do swoich penitentek ${ }^{79}$.

Ciągle na historyków czeka przebadanie obecności innych poza zmartwychwstańcami polskich księży w państwach włoskich w XIX wieku. Kilkakrotnie w tym artykule wspomniano o jezuitach. Trzeba pamiętać, że we Włoszech jezuici polscy przebywali głównie w Rzymie, gdzie pracowali w Kurii Generalnej, studiowali w Collegium Romanum oraz pełnili obowiązki penitencjarzy w Bazylice św. Piotra. Do kasaty zakonu w 1773 roku jezuici spowiadali również pielgrzymów polskich w Loreto. Po wydaleniu jezuitów z Rosji w 1820 roku wielu zakonników udało się do Włoch. W samej prowincji turyńskiej przebywało dłużej lub krócej 28 jezuitów z ziem białoruskich. Po utworzeniu w 1820 roku od nowa Kurii Generalnej w Rzymie pracowało w niej kilku jezuitów z przedrozbiorowej Rzeczypospolitej, m.in. Rajmund Brzozowski, Jan Rozaven, Jan Antoni Grassi, Alojzy Landes i Jakub Perling. Jezuici ci znający język polski utrzymywali kontakt z Polonią i księżmi znad Wisły ${ }^{80}$. Po kasacie jezuitów papież Klemens XIV wydał w 1774 roku konstytucję apostolską Miserator Dominus, w której powierzył pełnienie obowiązków penitencjarzy w Bazylice św. Piotra franciszkanom konwentualnym, wśród nich był również spowiednik apostolski dla Polaków. W Rzymie pierwszym spowiednikiem apostolskim z zakonu franciszkanów był o. Pankracy Kalitowicz w latach 1771-1777. W roku jubileuszowym 1775, kiedy napływ pielgrzymów do Rzymu

75 L. Henczel-WróblewsKa, Polacy, s. 60-85, 107, 111.

${ }^{76}$ K. Morawski, Polska $i$ Włochy $w$ walce o niepodległość, „Polityka Narodów” 7(1936), z. 5 , s. 522 .

${ }^{77}$ H. Kajsiewicz do Braci w Paryżu, Livarno, 6 XI 1846, w: H. KAJsiewicz, Listy, t. III, s. 183.

${ }^{78}$ H. Kajsiewicz do A. Jełowickiego, Rzym, 13 VI 1856, w: H. KaJsIEwicz, Listy, t. VI, s. 200.

${ }^{79}$ H. Kajsiewicz do A. Jełowickiego, Rzym, 21 VI 1856, w: tamże, s. 202.

${ }^{80}$ Encyklopedia wiedzy o jezuitach, s. 593, 751. 
zwiększył się wielokrotnie, drugim penitencjarzem został o. Marceli Jurkiewicz. Rozbiory spowodowały poważne trudności w obsadzie urzędu polskiego spowiednika w stolicy chrześcijaństwa, głównie z powodu trudności z wyjazdem za granicę. $\mathrm{Z}$ tego względu trudno ustalić listę polskich spowiedników apostolskich w Rzymie. W ich wykazie jest wymieniony, jako następca o. Marcelego Jurkiewicza, o. Piotr Rutkiewicz. W innych dokumentach z końca XVIII wieku wzmiankowani byli jako spowiednicy apostolscy o. Dymitr Orchowski z prowincji ruskiej (1778) i o. Franciszek Kwieciński (1786), zaś w latach 1790-1805 Franciszek Laudański z prowincji litewskiej. W 1825 roku zarząd zakonu franciszkanów starał się o sprowadzenie spowiedników do Padwy, gdzie liczni Polacy przybywali do grobu św. Antoniego, ale nie udało się tego zrealizować. W pierwszej połowie XIX wieku faktycznie wystąpił brak polskich spowiedników w Rzymie. Na skutek interwencji generała zakonu o. Angelo Bigoniego w ambasadzie rosyjskiej w Rzymie o. Prosper Paluchowski otrzymał pozwolenie na wyjazd do Włoch i w 1841 roku objął obowiązki spowiednika apostolskiego. Znanym spowiednikiem apostolskim Polaków w Loreto (1850-1868) był franciszkanin o. Kalikst Doboss, były profesor teologii moralnej ze Lwowa. O. Prosper Paluchowski pełnił obowiązki penitencjarza apostolskiego w Bazylice św. Piotra w Rzymie aż do śmierci w 1868 roku. Po nim obowiązki te przejął o. Doboss, który z Loreto przyjechał do Wiecznego Miasta ${ }^{81}$. Oprócz jezuitów i franciszkanów, w Wiecznym Mieście i krajach włoskich przebywali przedstawiciele innych zakonów, księża i misjonarze z polskich diecezji. Jednakże ustalenie ich nazwisk i działalności duszpasterskiej wymaga kwerendy źródłowej, głównie w archiwach zakonnych domów generalnych w Rzymie.

Poza zmartwychwstańcami przebywało we Włoszech kilku innych emigrantów polistopadowych, którzy zostali kapłanami. Franciszek Mikulski, podoficer artylerii w powstaniu listopadowym, znalazł się najpierw we Francji, a następnie w Rzymie, gdzie związał się początkowo z dominikanami, potem z franciszkanami. Około 1841 roku mieszkał w klasztorach franciszkańskich w Osimo pod Ankoną i Asyżu. Inny emigrant, Wincenty Kraiński, po uzyskaniu święceń kapłańskich w Rzymie w 1846 roku, postanowił poświęcić się misjom. Wyjechał wówczas do Neapolu i miast włoskich, a w późniejszym okresie osiadł we Wrocławiu ${ }^{82}$. Wspomnieć należy o obecności polskich kapelanów w czasie wojen prowadzonych na Półwyspie Apenińskim. Poeta Adam Mickiewicz na początku 1848 roku udał

${ }^{81}$ A. Zwiercan, Działalność franciszkanów wśród Polonii 1772-1976, „Studia Polonijne” 3(1979), s. $92-95,97$.

82 J. KuZICKI, Nieść wiarę, s. 69-70, 518-519; R. ERGETOwSKI, Wincenty Kraiński - lektor języka polskiego i rosyjskiego na Uniwersytecie Wroctawskim (1851-1880), w: Literatura, prasa, biblioteka. Studia i szkice ofiarowane Profesorowi Jerzemu Jarowieckiemu w 65-lecie urodzin i 40-lecie pracy naukowej, red. J. Szocki, K. Woźniakowski, Kraków 1997, s. 378. 
się do Rzymu, gdzie zamierzał utworzyć legion polski. Zabiegał tam o dobre stosunki z przedstawicielami Hotelu Lambert i zmartwychwstańcami, a jednocześnie w Lombardii planował utworzyć oddział złożony z emigrantów. Wiosną 1848 roku udało się poecie zawiązać legion w Piemoncie. Do Mediolanu udał się wówczas ks. Józef Stankiewicz, który z Francji przybył z kolumną ochotników dowodzonych przez płka Mikołaja Korwin-Kamieńskiego. Jednakże w kwietniu 1849 roku ks. Stankiewicz wskutek intryg opuścił oddział. Po wkroczeniu Legionu Mickiewicza do Rzymu, wobec polskich księży pojawiły się oskarżenia o zniechęcanie emigrantów do tej formacji. Prowadzono nawet śledztwo, księżom grożono sądem. W wydarzenia tzw. rewolucji rzymskiej włączyło się dwóch polskich duchownych z Francji: Julian Skirmunt i Szymon Franciszek Lisowski. Nikt natomiast ze stale przebywających w Wiecznym Mieście polskich kapłanów nie poparł republikanów rzymskich. W czasie wojny Piemontu i Francji przeciw Austrii w 1859 roku zmartwychwstańcy otrzymali propozycję opieki duszpasterskiej w szpitalach jenieckich, gdzie przebywało wielu Polaków z Galicji. Do Mediolanu wyjechał latem 1859 roku ks. Marcin Kwiatkowski, który przejął obowiązki kapelana w szpitalach piemonckich ${ }^{83}$.

W drugiej połowie XIX wieku, pomimo załamania się działań politycznych Polaków w Rzymie, Włochy nadal przyciągały polskich pielgrzymów, artystów, literatów, a także uczonych. Wśród nowych peregrynantów pojawiły się grupy chłopów, którzy dotarli tutaj już w 1877 roku z okazji jubileuszu. Na pomoc i opiekę mogli oni liczyć u rzymskich zmartwychwstańców. Poprzez przybliżenie tej tematyki autor ma nadzieję, że znajdą się historycy, którzy szczegółowo opracują dzieje duszpasterstwa polskiej emigracji na Półwyspie Apenińskim. Z pewnością wiele źródeł mogą dostarczyć przeogromne zbiory archiwum watykańskiego. Wśród poloników znajdujących się w dokumentach Sekretariatu Stanu, archiwum osobistym dziewiętnastowiecznych papieży (szczególnie Piusa IX) oraz w aktach nuncjatur i przedstawicielstw dyplomatycznych można wskazać m.in. materiały dotyczące duchowieństwa polskiego na emigracji, Polaków pielgrzymujących i podróżujących ${ }^{84}$. Oczywiście duże możliwości badawcze stwarzają inne włoskie i watykańskie biblioteki i archiwa. Jak pisze ks. Hieronim Fokciński SJ, zbiory biblioteczne i archiwalne Kościoła i Hospicjum św. Stanisława przy via Botteghe Oscure, Papieskiego Kolegium Polskiego na Piazza Remuria, Polskiego Papieskiego Instytutu Studiów Kościelnych przy via Cavallini można szacować na kilkanaście

83 J. KuZICKI, Nieść wiare, s. 332-333, 364, 502.

84 J. KuZICKI, Specyfika badań nad duchowieństwem Wielkiej Emigracji (1831-1863), w: W kręgu badań nad Polonia i duszpasterstwem polonijnym. Istota i metodologia, red. S. Zych, B. Walicki, Lublin-Sokołów Małopolski 2015, s. 314. 
tysięcy archiwaliów, książek i czasopism. W tych samych wielkościach mieszczą się zbiory domów generalnych polskich zgromadzeń, męskich i żeńskich. W niektórych kolekcjach źródłowych i bibliotecznych istnieją wyodrębnione działy polskie, jak np. w Watykańskiej Bibliotece Apostolskiej (Biblioteca Apostolica Vaticana). Powiązania historyczne, rozwinięte kontakty z bliskimi nam obszarami geograficznymi sprawiły, że w wielu kolekcjach polonika mają swoją reprezentację. Przykładowo można wspomnieć o instytutach: austriackim, niemieckim, rosyjskim, watykańskim, Pontificio Istituto Orientale czy zbiorach bazyliańskich, ormiańskich ${ }^{85}$.

\section{BIBLIOGRAFIA}

\section{Źródła archiwalne}

\section{Archiwum Ministerstwa Obrony Francji (Service Historique de l'Armée de Terre - SHAT)}

XL - 9a-f lère Légion de la Vistule: dossiers des 4 régiments. Réfugiés polonais sous le ler Empire : pièces individuelles A à Z.

\section{Archiwum Zgromadzenia Zmartwychwstania Pańskiego w Rzymie. Archivum Congregationis a Resurrectione, Romae [ACRR]}

sygn. 17201, A. Jełowicki do H. Kajsiewicza, Rzym, 17 III 1844.

sygn. 17207, A. Jełowicki do H. Kajsiewicza, Rzym, 18 I 1845.

sygn. 17210, A. Jełowicki do H. Kajsiewicza, Rzym, 8 III 1845.

sygn. 17212, A. Jełowicki do H. Kajsiewicza, Rzym, 3 IV 1845.

sygn. 17189, A. Jełowicki do J. Hubego, Rzym, 20 X 1843.

sygn. 17206, A. Jełowicki do H. Kajsiewicza, Rzym, 28 XI 1844.

sygn. 17761, A. Jełowicki do H. Kajsiewicza, 20 XII 1856.

sygn. 17767, A. Jełowicki do H. Kajsiewicza, 28 II 1857.

\section{Biblioteka Czartoryskich w Krakowie [BCz]}

rkps 5374 IV - X[iążę] A[dam] C[zartoryski]. Rome. Correspondances avec le Pape 1840 à [18]41. Tome II.

rkps 5374 IV, k. 303-313, M. Czajkowski do A. J. Czartoryskiego, 1840 z Rzymu.

rkps 5375 IV - X[iążę] A[dam] C[zartoryski]. Rome. Correspondances avec le Pape 1842

à [18]43. Tome III.

${ }^{85}$ H. FoKCIŃSKI, Polsko-emigracyjne i polonijne dziedzictwo piśmiennicze w zbiorach rzymskich $i$ włoskich, „Z Badań nad Książką i Księgozbiorami Historycznymi” 2017, tom specjalny, s. 481-494. 
rkps 5376 IV - X[iążę] A[dam] C[zartoryski]. Rome. Correspondances avec le Pape 1844 à [18]46. Tome IV.

rkps 5378 IV - X[iążę] A[dam] C[zartoryski]. Rome. Correspondances avec le Pape 1848

à [18]60. Tome VI.

rkps 5379 IV - X[iążę] A[dam] C[zartoryski]. Rome. Correspondance de Czaykowski 1840 à [18]42. Tome VII.

rkps 5380 IV - X[iążę] A[dam] C[zartoryski]. Rome. Correspondances de L. Orpiszewski

1844 à [18]49. Tome VIII.

rkps 5381 IV - X[iążę] A[dam] C[zartoryski]. Rome. Diverses correspondances. Tome IX. rkps 5382 IV - Rzym 1848.

rkps 5622 IV, Correspondances, 1855. Tome I.

rkps 5681 IV, Lista imienna, 1853-1854-1855. Wykazy emigrantów polskich przebywających

we Francji, Anglii, Włoszech i Afryce.

rkps 5699 III, Agence romaine. Mai 1861 - septembre 1863.

rkps 5745 IV, Agence romaine. /Paris 1. 1863-1865.

rkps 5746 IV, Agence romaine. /Paris 1. 1863-1864. Archiwum agencyjne „Memoranda

i noty do Rządu Jego Świątobliwości".

rkps 6743, Archiwum Hotelu Lambert. Materiały dotyczące stosunków polsko-włoskich

w latach 1848-1849 oraz 1860-1863.

rkps 6747 IV, Archiwum Hotelu Lambert. „Rzym. Stolica Apostolska”. Korespondencja

Adama Jerzego Czartoryskiego z papieżem Piusem IX, 1848-1860.

rkps 6967 IV, Archiwum Hotelu Lambert. Władysław Zamoyski. Korespondencja.

\section{Źródla drukowane}

H. Kajsiewicz, Listy 1845-1847, t. III, red. T. Kaszuba, Rzym 2005.

H. Kajsiewicz, Listy 1848-1851, t. IV, red. T. Kaszuba, Rzym 2006.

H. Kajsiewicz, Listy 1852-1854, t. V, red. T. Kaszuba, Rzym.

H. Kajsiewicz, Listy 1855-1858, t. VI, red. T. Kaszuba, Rzym 2007.

Jenerał Zamoyski 1803-1868, t. III, 1832-1837, Poznań 1914; t. IV, 1837-1847, Poznań 1918;

t. V: 1847-1852, Poznań 1922; t. VI, 1853-1868, Poznań 1930.

A. Jełowicki do H. Kajsiewicza, Rzym, 17 III 1844, w: P. Smolikowski, Historia Zgromadzenia Zmartwychwstania Pańskiego. Podług źródeł rękopiśmiennych napisał [...], t. III, Kraków 1893, s. 131-132.

A. JeŁowicki, Kazania o świętych polskich i o Królowej Korony Polskiej tudzież nauki przedślubne, mowy pogrzebowe i kazania przygodne przez księdza... poprzedzone listami Ojca Świętego Piusa IX a zakończone dokumentami odnoszącymi się do założenia Seminarium Polskiego w Rzymie i nauką o roztropności chrześcijańskiej św. Wincentego à Paulo, Berlin 1872.

A. JeŁowicki, Kazania na święta patronów polskich i na rocznice narodowe, Lwów 1912. 


\section{Opracowania}

BALIŃSKi M., LiPIŃSKi T., Starożytna Polska pod względem historycznym, jeograficznym i statystycznym opisana przez, t. III, Warszawa 1846.

BARAŃSKA Anna, „Polska ambasador” przy Watykanie - Zofia z Branickich Odescalchi (1821-1886), w: Od Paryża do Irkucka... i dalej. Niecodzienne przypadki Polaków okresu niewoli narodowej, red. A. Barańska, E. Niebelski, Lublin: TN KUL 2017, s. 77-98.

BARAŃSKA Anna, Kościół i przemiany religijności w historii Polski XIX wieku, w: Historie Polski w XIX wieku, red. Andrzej Nowak, t. IV, Warszawa: Wydawnictwo DiG 2015.

BARYCZ Henryk, Spojrzenia w przeszłość polsko-włoską, Wrocław-Warszawa-Kraków: Ossolineum 1965.

BoreJSza Jerzy, Emigracja polska po powstaniu styczniowym, Warszawa: PWN 1966.

Borucki Marek, Polacy w Rzymie. Od czasów Mieszka I do Jana Pawła II, Warszawa: Książka i Wiedza 1995.

Caban Wiesław, Bieniek Paweł, Kardynał Włodzimierz Czacki (1835-1888) - współpracownik Piusa IX i Leona XIII, w: Duchowieństwo polskie w świecie. Materiały VII Międzynarodowego Sympozjum Biografistyki Polonijnej. Papieski Uniwersytet Urbaniański, Rzym, 17-18 października 2002, red. Agata i Zbigniew Judyccy, Toruń: Oficyna Wydawnicza Kucharski 2002, s. 38-42.

Działalność męskich zgromadzeń zakonnych wśród Polonii, red. Józef Bakalarz [i in.], Lublin: RW KUL 1982.

ERGETOWSKI Ryszard, Wincenty Kraiński - lektor języka polskiego i rosyjskiego na Uniwersytecie Wrocławskim (1851-1880), w: Literatura, prasa, biblioteka. Studia i szkice ofiarowane Profesorowi Jerzemu Jarowieckiemu w 65-lecie urodzin i 40-lecie pracy naukowej, red. Jerzy Szocki i Krzysztof Woźniakowski, Kraków: Wydawnictwo Naukowe WSP 1997.

FoKCIŃSKI Hieronim, Polsko-emigracyjne i polonijne dziedzictwo piśmiennicze w zbiorach rzymskich i włoskich, „Z Badań nad Książką i Księgozbiorami Historycznymi” 2017, tom specjalny, s. 481-494.

GrochOLEwSKi Zenon, Reprezentant polski w Kurii Rzymskiej. Kardynał Bolesław Jan Filipiak (1901-1978), w: Duchowieństwo polskie w świecie. Materiały VII Międzynarodowego Sympozjum Biografistyki Polonijnej. Papieski Uniwersytet Urbaniański, Rzym, 17-18 października 2002, red. Agata i Zbigniew Judyccy, Toruń: Oficyna Wydawnicza Kucharski 2002, s. 105-113.

Henczel-Wróblewska Ligia, Polacy w kulturze Piemontu w XIX wieku i w pierwszych dekadach XX wieku, Poznań: UAM 2014.

INGLOT Marek, Włodzimierz Ledóchowski SJ (1866-1842). Generał Towarzystwa Jezusowego, w: Duchowieństwo polskie w świecie. Materiały VII Międzynarodowego Sympozjum Biografistyki Polonijnej. Papieski Uniwersytet Urbaniański, Rzym, 17-18 października 2002, red. Agata i Zbigniew Judyccy, Toruń: Oficyna Wydawnicza Kucharski 2002, s. 130-135. 
KalembKa Sławomir, Polskie wychodźstwa popowstaniowe i inne emigracje polityczne w Europie w XIX wieku, w: Polska XIX wieku. Państwo, społeczeństwo, kultura, red. Stefan Kieniewicz, Warszawa: Wiedza Powszechna 1977.

KalembKa Sławomir, Polskie zabiegi dyplomatyczne między powstaniem listopadowym a styczniowym (koniec 1831-1860 r.), w: Historia dyplomacji polskiej, t. III: 1795-1918, red. Ludwik Bazylow, Warszawa: PWN 1982.

KoŁodzIEJ Bernard, Opieka duszpasterska nad wychodźcami polskimi do roku 1939, Poznań: UAM 2003.

KopIEC Jan, Echa polskich wydarzeń z lat 1704-1709 w środowisku Hospicjum św. Stanisława w Rzymie, „Nasza Przeszłość” 1994, t. 82, s. 373-380.

KopIEC Jan, Ks. Walerian Meysztowicz (1893-1982). Dyplomata, prawnik i historyk w służbie swojego kraju, w: Duchowieństwo polskie w świecie. Materiały VII Międzynarodowego Sympozjum Biografistyki Polonijnej. Papieski Uniwersytet Urbaniański, Rzym, 17-18 października 2002, red. Agata i Zbigniew Judyccy, Toruń: Oficyna Wydawnicza Kucharski 2002, s. 143-149.

KorZENIOwsKi Ireneusz, Polacy we Włoszech. Zarys historii, duszpasterstwa, organizacji i prasy, „Studia Polonijne” 21(2000), s. 122-123.

KozŁowsKi Jerzy, Emigracja okresu schyłkowego Rzeczypospolitej szlacheckiej i porozbiorowa, w: Emigracja z ziem polskich w czasach nowożytnych i najnowszych (XVIII-XX w.), red. Andrzej Pilch, Warszawa: PWN 1984.

KuzICKI Jerzy, Duchowieństwo Wielkiej Emigracji na Wyspach Brytyjskich (1831-1863), „Studia Polonijne” 32(2011), s. 6-33.

KUZICKI Jerzy, Nieść wiarę i nadzieję na obcej ziemi. Polskie duchowieństwo katolickie w życiu religijnym i polityczno-społecznym Wielkiej Emigracji we Francji (1831-1863), Rzeszów: Wydawnictwo URz 2014.

KuzICKI Jerzy, Stronnictwo konserwatywno-liberalne Wielkiej Emigracji wobec grekokatolików w Galicji, w: Cirkvi a národy strednej Európy (1800-1950), zestavili Peter Švorc, Lubica Harbul'ová, Karl Schwarz, Prešov-Wien 2008, s. 181-192.

KuZICKi Jerzy, Specyfika badań nad duchowieństwem Wielkiej Emigracji (1831-1863), w: W kręgu badań nad Polonią i duszpasterstwem polonijnym. Istota i metodologia, red. S. Zych, B. Walicki, Lublin-Sokołów Małopolski 2015, s. 314.

KwiatKowska Anna, „Pod urokiem Italii” - Podróże polskich pisarzy do Włoch, w: Polonia włoska. Wybór artykułów z Biuletynu Informacyjnego „Polonia Włoska” z lat 1995-2009, wybór i opracowanie tekstów Ewa Prządka, Anna Kwiatkowska, Rzym: Związek Polaków we Włoszech 2010.

KwiatKowska Maria I., Groby polskie na cmentarzach Rzymu, Warszawa: Wydawnictwo Instytut Sztuki PAN 1999.

KwiatKowska Maria I., Polacy w Rzymie w wiekach XIX-XX, Warszawa: Muzeum Wychodźstwa Polskiego im. Ignacego Paderewskiego 2007.

LePaCKa Anna M., Początki Kolegium Polskiego w Rzymie, „Studia Warmińskie” 50(2013), s. $263-269$.

Lorenc-Antonangeli Halina, Potomkowie księcia Stanisława Poniatowskiego, w: Polonia włoska. Wybór artykułów z Biuletynu Informacyjnego „Polonia Włoska” z lat 
1995-2009, wybór i opracowanie tekstów Ewa Prządka, Anna Kwiatkowska, Rzym: Związek Polaków we Włoszech 2010.

MacheJEK Michał, 400 lat Kościoła i hospicjum św. Stanisława w Rzymie, Rzym: Hosianum 1978.

Micewski Bolesław, Polonijna działalność zmartwychwstańców, w: Działalność męskich zgromadzeń zakonnych wśród Polonii, red. Józef Bakalarz [i in.], Lublin: RW KUL 1982.

Misztal Henryk, Duszpasterstwo Polonii włoskiej, „Studia Polonijne” 1(1976).

MorAwski Kalikst, Polacy i sprawa polska w dziejach Italii w latach 1830-1866, Warszawa 1930.

MoraWski Kalikst, Polska i Włochy w walce o niepodległość, „Polityka Narodów” 7(1936), z. 5.

PACHOŃsKi Jan, Korpus oficerski Legionów Polskich 1796-1807, Kraków: Księgarnia Akademicka 1999.

PAchoŃski Jan, Legiony Polskie. Prawda i legenda 1794-1807, t. I: Działalność niepodległościowa i zaczątki Legionów 1794-1797, Warszawa: MON 1976.

PaChoŃski Jan, Legiony Polskie. Prawda i legenda 1794-1807, t. II: Zwycięstwa i klęski 1797-1799, Warszawa: MON 1976.

PrządKa Ewa, Matka Boska Przedziwna - Mater Admirabilis w klasztorze Trinità dei Monti w Rzymie, w: Polonia włoska. Wybór artykułów z Biuletynu Informacyjnego „Polonia Włoska” z lat 1995-2009, wybór i opracowanie tekstów Ewa Prządka, Anna Kwiatkowska, Rzym: Związek Polaków we Włoszech 2010.

StęPIEŃ Marek, Początki Kolegium Polskiego w Rzymie w XVI i XVII w. oraz działania zmierzające do jego utworzeia w XIX w., „Prawo Kanoniczne” 53(2010), nr 1-2.

Szymański Józef, Duszpasterstwo polonijne - skala oddziaływania, „Studia Polonijne” 28(2007).

ŚLADKOwSKI Wiesław, Wychodźstwa polskiego zarys dziejowy, Lublin: Wydawnictwo UMCS 1994.

Urban Jan, Makryna Mieczysławska w świetle prawdy, Kraków: Nakład „Przeglądu Powszechnego" 1923.

Wkład Polaków do kultury świata, red. Mieczysław Krąpiec [i in.], Lublin: TN KUL 1976.

Wszolek Jan, Działalność polityczna obozu Czartoryskiego wśród Polaków w Rzymie w latach 1832-1843, „Przegląd Historyczny” 58(1967), z. 4, s. 625-643.

ZARĘBCZAN Władysław, Polscy pracownicy naukowi na papieskich uczelniach w Rzymie, w: Duchowieństwo polskie w świecie. Materiały VII Międzynarodowego Sympozjum Biografistyki Polonijnej. Papieski Uniwersytet Urbaniański, Rzym, 17-18 października 2002, red. Agata i Zbigniew Judyccy, Toruń: Oficyna Wydawnicza Kucharski 2002, s. 383-396.

ZıóŁeK Ewa M., Duszpasterstwo w wojsku Księstwa Warszawskiego, Królestwa Polskiego i w powstaniu listopadowym, w: Historia duszpasterstwa wojskowego na ziemiach polskich, red. Jan Ziółek, Anna Barańska, Witold Matwiejczyk, Dariusz Nawrot, Ewa M. Ziółek, Lublin: TN KUL 2004.

ZwIERCan Antoni, Działalność franciszkanów wśród Polonii 1772-1976, „Studia Polonijne” 3(1979), s. 92-97. 


\section{Slowniki}

Encyklopedia katolicka, t. I-XVIII, Lublin: TN KUL 1973-2013.

Encyklopedia polskiej emigracji i Polonii, red. Kazimierz Dopierała, t. I-V, Toruń: Oficyna Wydawnicza Kucharski 2003-2005.

Encyklopedia wiedzy o jezuitach na ziemiach Polski i Litwy 1564-1995, opracował Ludwik Grzebień, Kraków: WAM 1996.

JudYCCY Agata i Zbigniew, W służbie Bogu i światu. Słownik biograficzny. Polscy i polskiego pochodzenia kapłani, zakonnicy i siostry zakonne pełniący posługę w różnych krajach świata, Toruń: Oficyna Wydawnicza Kucharski 2002.

JuDYCCY Agata i Zbigniew, Polonia. Słownik biograficzny, Warszawa: Wydawnictwo Naukowe PWN 2000.

JuDYCKI Zbigniew, Polscy duchowni w świecie. Słownik biograficzny, t. I, Kielce: Józef Siwek 2008.

KACHEL Józef, Bernardyni 1453-2003. Kapłani i bracia zakonni prowincji polskich oraz kustodii św. Michała na Ukrainie, cz. V, R-T, Warta: Klasztor Ojców Bernardynów 2004. Misjonarze św. Wincentego à Paulo w Polsce (1651-2001), t. II-1: Biografie, red. Jan Dukała, Kraków: Instytut Wydawniczy Księży Misjonarzy „Nasza Przeszłość” 2001.

Polski słownik biograficzny, t. I-III, Kraków: Ossolineum 1935-2018.

ZARĘBCZAN Władysław, Polacy w Watykanie, Pelplin: Bernardinum 2004.

\section{Netografia}

http://www.biz.xcr.pl/files/KAJSIEWICZ-Pamietnik-o-Poczatkach-CR.pdf [dostęp: 09.07. 2018]. Tekst oryginalny za: Pisma X. Hieronima Kajsiewicza ze Zgromadzenia Zmartwychwstania Pańskiego, t. III, Rozprawy, Listy z podróży, Pamiętnik o Zgromadzeniu, Berlin [w Księgarni B. Behra (E. Bock)] - Kraków [w Księgarni D. E. Friedleina], 1872, s. 402-527. Komputerowe opracowanie tekstu: Michał Szlachciak CR.

\section{DUSZPASTERSTWO EMIGRACJI POLSKIEJ W RZYMIE \\ I INNYCH KRAJACH WŁOSKICH W LATACH 1795-1863: \\ OKOLICZNOŚCI POWSTANIA, POSTULATY I KIERUNKI BADAWCZE}

\section{Streszczenie}

Niniejszy artykuł jest szkicem ukazującym okoliczności powstania oraz funkcjonowanie duszpasterstwa emigracji polskiej w Rzymie i innych krajach włoskich w latach 1795-1863. Działalność placówek duszpasterstwa polonijnego oznaczała uwzględnienie odmiennego stylu duszpasterzowania poprzez dopuszczenie różnych elementów, właściwych rodzinnej religijności. Polska historiografia może pochwalić się szeregiem artykułów i słowników, w których znajdują się dane odnośnie do duchownych pracujących wśród emigrantów w krajach włoskich. Pomimo tego tematyka duszpasterstwa polskiego w pierwszej po- 
łowie XIX wieku w Państwie Kościelnym i Włoszech wymaga szczegółowych badań. Monograficzne opracowanie tego zagadnienia historycznego musi poprzedzać wieloletnia kwerenda źródłowa w polskich i zagranicznych archiwach i bibliotekach. Obok prezentacji ustaleń, autor wskazał postulaty badawcze związane z podjętą problematyką oraz przybliżył źródła z archiwum zmartwychwstańców w Rzymie, archiwum Czartoryskich w Krakowie, dokumenty wydane drukiem. Tematyka tutaj zaprezentowana, jak sądzi autor, powinna stanowić inspirację do całościowych studiów nad duszpasterstwem polonijnym na Półwyspie Apenińskim w XIX stuleciu.

Słowa kluczowe: Polacy w Rzymie i Państwie Kościelnym; duszpasterstwo emigracji polskiej; pierwsza połowa XIX wieku

\author{
PASTORAL CARE FOR POLISH CITIZENS IN ROME \\ AND OTHER ITALIAN COUNTRIES \\ IN THE YEARS 1795-1863: \\ BACKGROUND, POSTULATES AND RESEARCH DIRECTIONS
}

\begin{abstract}
Sum mary
This article is a sketch showing the background and the functioning of the pastoral care for Polish citizens in Rome and other Italian countries in the years 1795-1863. The activities of the Polish pastoral care institutions meant taking into account a different pastoral style by admitting various elements of family religiosity. There are many articles and dictionaries in Polish historiography, in which there are data about clerics working among expatriates in Italian countries. Nevertheless, the subject of Polish pastoral care in the first half of the $19^{\text {th }}$ century in the Papal States and Italy requires detailed research. The monographic development of this historical issue must be preceded by a long-term source query in Polish and foreign archives and libraries. In addition to the presentation of the findings, the author pointed out research postulates related to the issues raised and described the sources from the Roman Archive of the Congregation of the Resurrection, the Princes Czartoryski Archives from Krakow, and printed documents. The subject matter presented here, as the author thinks, should be an inspiration for a comprehensive study of the pastoral care for Polish residents of the Apennine Peninsula in the $19^{\text {th }}$ century.
\end{abstract}

Key words: Poles in Rome and in the Papal States; pastoral care for Polish citizens; first half of the $19^{\text {th }}$ century 